\title{
Design, Synthesis, Biological Evaluation and In Silico Study of Benzyloxybenzaldehyde Derivatives as Selective ALDH1A3 Inhibitors
}

\author{
Ali I. M. Ibrahim ${ }^{1, *(D)}$, Balqis Ikhmais ${ }^{1}$, Elisabet Batlle ${ }^{2,3}$, Waed K. AbuHarb ${ }^{1}$, Vibhu Jha ${ }^{4}$, \\ Khaled T. Jaradat ${ }^{5}$ (D), Rafael Jiménez ${ }^{3}$, Raquel Pequerul ${ }^{3}$, Xavier Parés ${ }^{3}$, Jaume Farrés ${ }^{3}$ and Klaus Pors ${ }^{2, *}$ (D) \\ 1 Faculty of Pharmacy, Al-Zaytoonah University of Jordan, Amman 11733, Jordan; b.ikhmais@zuj.edu.jo (B.I.); \\ waedkhalil1997@gmail.com (W.K.A.) \\ 2 Faculty of Life Sciences, Institute of Cancer Therapeutics, School of Pharmacy and Medical Sciences, \\ University of Bradford, Bradford BD7 1DP, UK; e.batllerocafort@bradford.ac.uk \\ 3 Department of Biochemistry and Molecular Biology, Faculty of Biosciences, Universitat Autònoma de \\ Barcelona, E-08193 Barcelona, Spain; rafael.jimenez@uab.cat (R.J.); raquel.pequerul@gmail.com (R.P.); \\ xavier.pares@uab.cat (X.P.); jaume.farres@uab.cat (J.F.) \\ 4 Department of Pharmacy, University of Pisa, 56126 Pisa, Italy; vibhujha16@gmail.com \\ 5 College of Engineering and Technology, American University of the Middle East, Kuwait City 54200, Kuwait; \\ khaled.jaradat@aum.edu.kw \\ * Correspondence: a.ibrahim@zuj.edu.jo (A.I.M.I.); k.pors1@bradford.ac.uk (K.P.)
}

Citation: Ibrahim, A.I.M.; Ikhmais, B.; Batlle, E.; AbuHarb, W.K.; Jha, V.; Jaradat, K.T.; Jiménez, R.; Pequerul, R.; Parés, X.; Farrés, J.; et al. Design, Synthesis, Biological Evaluation and In Silico Study of

Benzyloxybenzaldehyde Derivatives as Selective ALDH1A3 Inhibitors. Molecules 2021, 26, 5770. https://doi.org/10.3390/molecules 26195770

Academic Editor: Patricia Dias Fernandes

Received: 6 August 2021

Accepted: 13 September 2021

Published: 23 September 2021

Publisher's Note: MDPI stays neutral with regard to jurisdictional claims in published maps and institutional affiliations.

Copyright: (c) 2021 by the authors. Licensee MDPI, Basel, Switzerland. This article is an open access article distributed under the terms and conditions of the Creative Commons Attribution (CC BY) license (https:/ / creativecommons.org/licenses/by/ $4.0 /)$.
Abstract: Aldehyde dehydrogenase 1A3 (ALDH1A3) has recently gained attention from researchers in the cancer field. Several studies have reported ALDH1A3 overexpression in different cancer types, which has been found to correlate with poor treatment recovery. Therefore, finding selective inhibitors against ALDH1A3 could result in new treatment options for cancer treatment. In this study, ALDH1A3-selective candidates were designed based on the physiological substrate resemblance, synthesized and investigated for ALDH1A1, ALDH1A3 and ALDH3A1 selectivity and cytotoxicity using ALDH-positive A549 and ALDH-negative H1299 cells. Two compounds (ABMM-15 and ABMM-16), with a benzyloxybenzaldehyde scaffold, were found to be the most potent and selective inhibitors for ALDH1A3, with $\mathrm{IC}_{50}$ values of 0.23 and $1.29 \mu \mathrm{M}$, respectively. The results also show no significant cytotoxicity for ABMM-15 and ABMM-16 on either cell line. However, a few other candidates (ABMM-6, ABMM-24, ABMM-32) showed considerable cytotoxicity on H1299 cells, when compared to $\mathrm{A} 549$ cells, with $\mathrm{IC}_{50}$ values of $14.0,13.7$ and $13.0 \mu \mathrm{M}$, respectively. The computational study supported the experimental results and suggested a good binding for ABMM-15 and ABMM-16 to the ALDH1A3 isoform. From the obtained results, it can be concluded that benzyloxybenzaldehyde might be considered a promising scaffold for further drug discovery aimed at exploiting ALDH1A3 for therapeutic intervention.

Keywords: aldehyde dehydrogenase; ALDH1A1; ALDH1A3; ALDH3A1; A549 cells; H1299 cells; non-small cell lung cancer; cytotoxicity; in silico

\section{Introduction}

The aldehyde dehydrogenase (ALDH) superfamily is a group of $\mathrm{NAD}(\mathrm{P})^{+}$-dependent enzymes comprised by 19 different human isoforms widely distributed and diversely expressed in the body tissues [1]. The main function of these enzymes is to catalyze the oxidation of both endogenous and exogenous aldehydes to their corresponding carboxylic acids [1]. Several ALDH isoforms, mainly ALDH1A isoforms, are involved in the biosynthetic oxidation of retinaldehyde to retinoic acid (RA), the physiologically active metabolite of vitamin A [2,3]. RA is a well-known regulator of cell-signaling pathways during embryonic development, which acts through binding to the nuclear retinoic acid receptors (RARs and RXRs), and has been found to be involved in the diverse modulatory roles of 
the differentiation and proliferation of normal cells by modulating gene transcription $[4,5]$. In cancer, it has been hypothesized that the replicating cancer cells are derived from a small subpopulation of cancer stem cells (CSCs) or tumor-initiating cells, in which RA-mediated signaling pathways are essential for their proliferation and differentiation [6-8]. The importance of identifying ALDH activity during CSC differentiation and cancer initiation has been extensively reviewed and remarked [9-11].

Different isoforms of the ALDH1 subfamily have been commonly described as biomarkers for CSCs in several cancer cell types [12,13], where both ALDH1A1 and ALDH1A3 are highly expressed in stem-cell-like subpopulations of different cancer types $[14,15]$. In particular, ALDH1A3 targeting has been investigated for its potential clinical applications in several cancer types, including metastatic breast cancer [16], non-small-cell lung cancer (NSCLC) [17] and mesenchymal subtype gliomas [18]. In addition, ALDH1A3 expression has been correlated with poor prognosis in breast cancer [19], chemoresistance of mesothelioma [20] and radioresistance of head and neck cancer [21], and its inhibition has been proven to induce the cytotoxicity of those cancer cells that present an ALDH1A3 overexpression $[19,22]$. Moreover, ALDH1A3 downregulation has been found to reduce CD44 and epithelium-specific antigen, as well as CSCs isolated from breast cancer [23].

Targeting ALDHs through the analysis of their catalytic centers has been implemented [24-26]. Although ALDH1A3 is a tetramer, each monomer can work independently, with a $\mathrm{NAD}(\mathrm{P})^{+}$-binding pocket and a substrate-binding pocket. The latter is occupied by a strictly conserved catalytic cysteine residue (Cys314 in ALDH1A3 or Cys303 in ALDH1A1 according to original numbering [27]), which is essential for the active-site nucleophilic attack. Alongside, there are several aromatic amino acid residues, such as Trp189 or Tyr472 (ALDH1A3 numbering), all contributing to the substrate-binding pocket [28-30]. An indepth knowledge of the isoform-specific ALDH active sites has been found helpful in drug discovery, not only in the design of compounds based on the substrate-binding pocket architecture, but also in calculating and predicting the affinity and binding interactions of substrates and inhibitors [31].

The modulation of ALDH isoforms with small molecules has been a matter of interest in recent years [32-34]. A well-known and widely used compound is diethylamino benzaldehyde (DEAB), commonly exploited as a pan-inhibitor for ALDH enzymes, but it was found to have a variable modulating activity by either working as a substrate, an inhibitor or both [35]. The binding interaction between DEAB and ALDH7A1 active site has been identified, whereby the contribution of the benzaldehyde moiety of DEAB with the aromatic and nucleophilic amino acids of the catalytic center has been highlighted [26]. Nevertheless, DEAB remains a small molecule with limited functional groups that binds unselectively to ALDH enzymes; hence, the search for isoform-targeting selective molecules remains of interest. This is of particular interest for those diseases where a transient or permanent imbalance in isoform-selective ALDH function and/or expression occur. Moreover, having isoform-selective inhibitors could be a useful tool to probe ALDH expression and activity in a more accurate way.

The approach presented in the current study may slightly differ from the classical design of molecules for ALDH inhibition, as the compounds here have been strategically developed to be recognized by the enzyme as substrates and form a stable enzyme-ligand complex that causes an inhibition. Therefore, three main structural aspects were taken into account to design a set of compounds that could potentially target ALDH1A3: First, extending the benzaldehyde moiety by a benzene ring to enhance the affinity toward the enzyme active site. This enhancement was predicted due to the existence of aromatic amino acids at the enzyme active sites, which may potentiate the intermolecular binding interactions. Second, the addition of a double bond between the aldehyde and benzene ring, attempting to relatively mimic the conjugation of retinoic acid (structure shown in Figure 1). Finally, the replacement of the aldehyde by an alcohol in some compounds and a carboxylic acid in another, to (i) evaluate its importance for both enzyme activity and 
cytotoxicity, and (ii) assess the outcomes of its removal, since it is the group that provides the ability of the compounds to act as ALDH substrates.

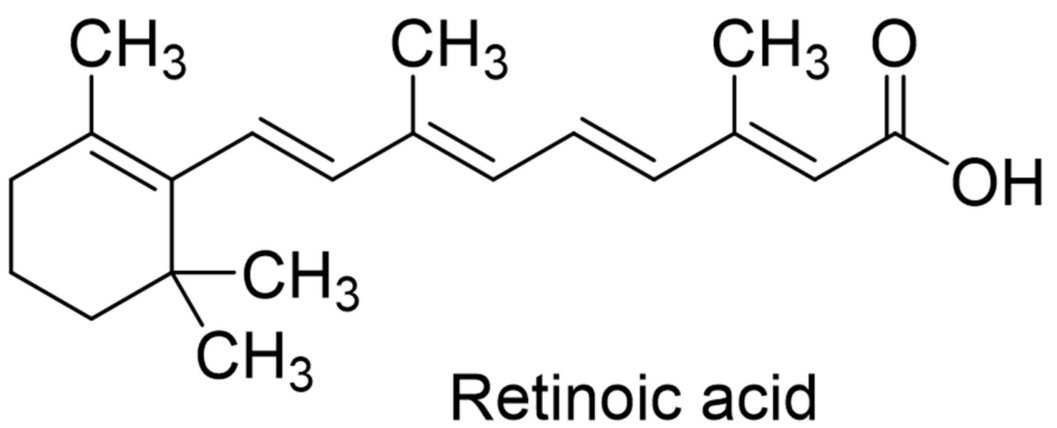

Figure 1. Chemical structure of retinoic acid.

Hence, the design of this library was based on the physiological substrate resemblance, aiming to achieve a high affinity for the substrate pocket but with an inhibitory effect. Scheme 1 shows a flow chart that describes our process of discovering a selective inhibitor for the ALDH1A3 isoform.

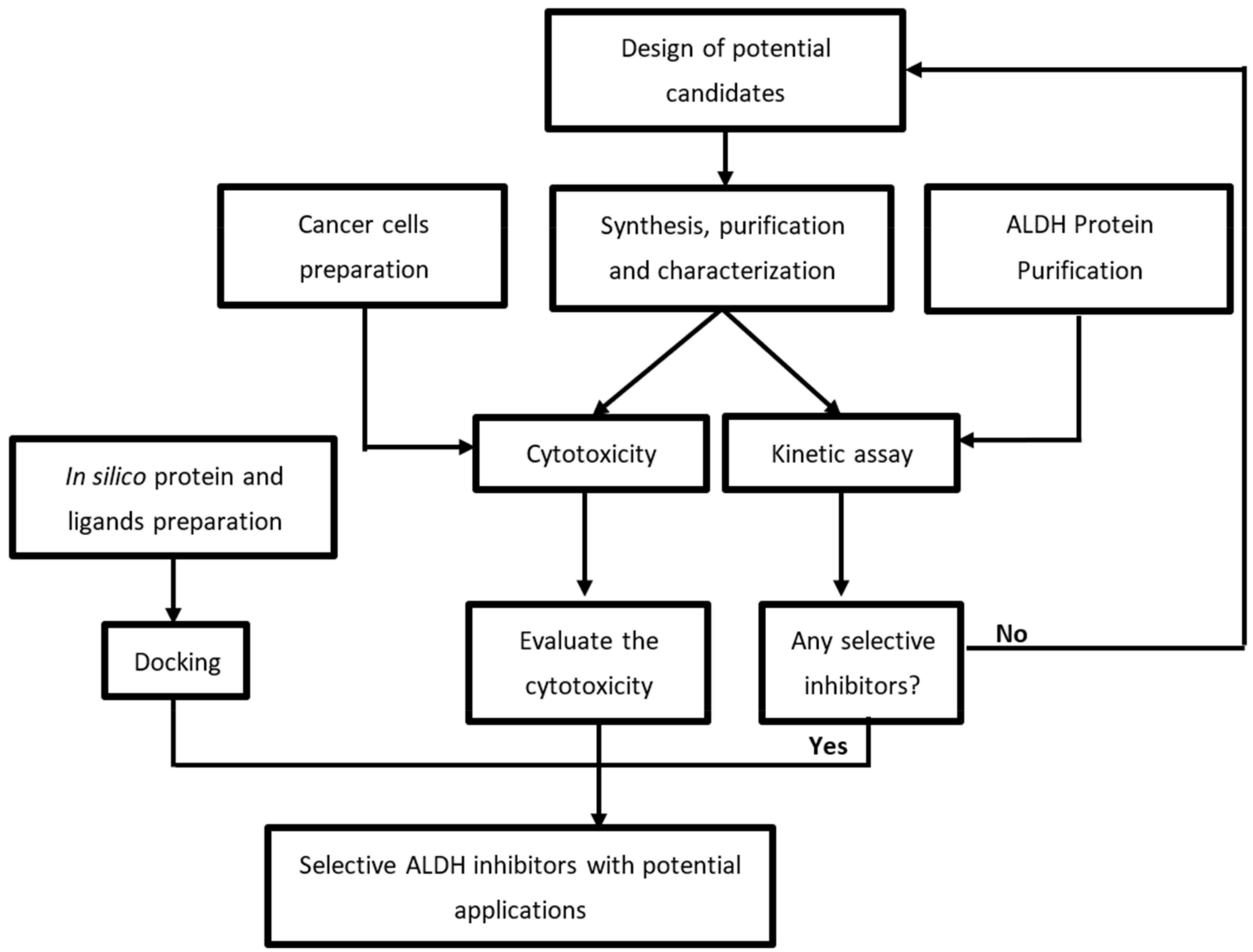

Scheme 1. Flow chart describing the discovery of ALDH1A3 selective inhibitors.

\section{Results and Discussion}

\subsection{Chemistry}

Several derivatives containing the phenylbenzoate and (benzyloxy)benzene scaffolds were synthesized by esterification (Scheme 2A) and O-alkylation (Scheme 2B) reactions, respectively. Compounds containing an aldehyde functionality were reduced to alcohols 
using sodium borohydride (Scheme 2C). The final compounds were either alcohols, aldehydes or carboxylic acids (Y group in Scheme 1) to enable their exploration as substrates with the purpose of inhibiting their catalytic functions, either reversibly or irreversibly. These compounds have the $\mathrm{Y}$ group connected to an aromatic ring either directly or through an olefinic bond in order to partially mimic the double-bond conjugation of retinoids. In addition, these compounds have two aromatic rings connected together by either an ester or a methyloxy group.

A<smiles>[R]c1ccc(C(=O)Cl)cc1</smiles><smiles>[R]c1cc(C)cc([R2])c1O</smiles><smiles></smiles>

01: $\mathbf{R}_{1}=\mathrm{Cl}, \mathrm{R}_{\mathbf{2}}=\mathrm{OCH}_{3}, \mathrm{R}_{3}=\mathrm{H}, \mathrm{Y}=\mathrm{CHO}$ 02: $\mathbf{R}_{1}=\mathrm{Cl}, \mathrm{R}_{\mathbf{2}}=\mathrm{H}, \mathrm{R}_{\mathbf{3}}=\mathrm{H}, \mathrm{Y}=\mathrm{CHO}$ 03: $R_{1}=F, R_{2}=H, R_{3}=H, Y=C H O$ 04: $R_{1}=$ NO2, $R_{2}=H, R_{3}=H, Y=C H O$ 05: $R_{1}=\mathrm{NO2}, \mathrm{R}_{2}=\mathrm{OCH}_{3}, \mathrm{R}_{3}=\mathrm{H}, \mathrm{Y}=\mathrm{CHO}$ 06: $R_{1}=F, R_{2}=O_{3}, R_{3}=H, Y=C=C-C H O$ 17: $R_{1}=F, R_{2}=--, R_{3}=H, Y_{\text {meta }}=\mathrm{CHO}$ 18: $R_{1}=F, R_{2}=O^{O C H}, R_{3}=O_{3} H_{3}, Y=C H O$ 27: $R_{1}=B r, R_{2}=H, R_{3}=H, Y=C=C-C O O H$ 28: $\mathrm{R}_{1}=\mathrm{CH} 2 \mathrm{Cl}, \mathrm{R}_{2}=\mathrm{OCH}_{3}, \mathrm{R}_{3}=\mathrm{H}, \mathrm{Y}=\mathrm{CHO}$ 32: $R_{1}=\mathrm{CH} 2 \mathrm{Cl}, \mathrm{R}_{2}=\mathrm{OCH}_{3}, \mathrm{R}_{3}=\mathrm{H}, \mathrm{Y}=\mathrm{CHO}$ 33: $R_{1}=N_{2}, R_{2}=O_{3} H_{3}, R_{3}=H, Y=C=C-C H O$ 34: $R_{1}=\mathrm{Cl}, \mathbf{R}_{2}=\mathrm{H}, \mathbf{R}_{\mathbf{3}}=\mathrm{H}, \mathrm{Y}_{\text {ortho }}=\mathrm{CHO}$
B<smiles>[X]Cc1ccc([R])cc1</smiles><smiles>[R]c1ccc(COc2c([Y])cc([R])cc2[R2])cc1</smiles>

15: $\mathrm{R}_{1}=\mathrm{Cl}, \mathrm{R}_{2}=\mathrm{H}, \mathrm{R}_{3}=\mathrm{H}, \mathrm{Y}=\mathrm{CHO}$ 16: $\mathbf{R}_{1}=\mathrm{Cl}, \mathrm{R}_{2}=\mathrm{OCH}_{3}, \mathrm{R}_{3}=\mathrm{H}, \mathrm{Y}=\mathrm{CHO}$ 24: $R_{1}=\mathrm{Br}, \mathrm{R}_{2}=\mathrm{OCH}_{3}, \mathrm{R}_{3}=\mathrm{H}, \mathrm{Y}=\mathrm{C}=\mathrm{C}-\mathrm{CHO}$ 26: $R_{1}=B r, R_{2}=H, R_{3}=H, Y=C=C-C O O H$<smiles>[Y]COC=CC=O</smiles>

19: R1 = F, $\mathrm{R}_{2}=\mathrm{OCH}_{3}, \mathrm{R}_{3}=\mathrm{H}, \mathrm{X}=\mathrm{CO}, \mathrm{Z}=\mathrm{C}=\mathrm{C}-\mathrm{CH} 2 \mathrm{OH}$ 23: $R 1=F, R_{2}=O_{C H}, R_{3}=O_{C H}, X=C O, Z=C H 2 O H$ 25: R1 = Br, R $\mathrm{R}_{\mathbf{2}}=\mathrm{OCH}_{3}, \mathrm{R}_{3}=\mathrm{OCH}_{3}, \mathrm{X}=\mathrm{CH}_{2}, \mathrm{Z}=\mathrm{C}=\mathrm{C}-\mathrm{CH} 2 \mathrm{OH}$ 35: $\mathrm{R}_{\mathbf{1}}=\mathrm{Cl}, \mathrm{R}_{\mathbf{2}}=\mathrm{H}, \mathrm{R}_{\mathbf{3}}=\mathrm{H}, \mathrm{Z}=\mathrm{CH}_{\mathbf{2}} \mathrm{OH}$

Scheme 2. Synthesis of the target $\mathrm{ABMM}$ compounds: (A) i: DMF, trimethylamine, r.t, overnight; (B) ii: $\mathrm{DMF} \mathrm{K}_{2} \mathrm{CO}_{3}, 80{ }^{\circ} \mathrm{C}$, overnight; (C) iii: $\mathrm{NaBH}_{4}$, methanol, r.t, 2 h.

\subsection{Inhibition Screening}

Nine compounds were tested at $10 \mu \mathrm{M}$ for their inhibitory effect against ALDH1A1, ALDH1A3 and ALDH3A1, as shown in Table 1. These compounds were selected to obtain preliminary data according to their structural diversity. The ALDH activity was determined by an enzymatic assay in which the substrate is oxidized in the presence of the cofactor $\mathrm{NAD}(\mathrm{P})^{+}$, generating $\mathrm{NAD}(\mathrm{P}) \mathrm{H}$, which is measured fluorimetrically with an excitation at $340 \mathrm{~nm}$ and emission at $460 \mathrm{~nm}$. The measured fluorescence increase per time unit is directly proportional to the ALDH activity rate. Hexanal or 4-NBA was used as the substrate due to their high catalytic efficiency [30]. The inhibition screening was preferably performed at a saturating substrate concentration except for ALDH1A3, where compounds were also tested at a substrate concentration near the $K_{m}$ value in order to obtain a wider preliminary inhibitory activity.

As shown in Table 1, none of the ABMM compounds showed significant inhibition of ALDH1A1 activity (lower than $30 \%$ of the remaining activity at $10 \mu \mathrm{M}$ ), with the lowest values $48 \%$ and $42 \%$ being obtained for compounds ABMM- 15 and ABMM-16, respectively. However, these two compounds showed promising inhibitory potency toward ALDH1A3, in which the remaining activity was $0.14 \%$ for ABMM- 15 and $4.27 \%$ for ABMM-16. ABMM- 
18 also resulted in a low remaining activity $(16 \%)$ against ALDH1A3 at a $K_{m}$ concentration, followed by ABMM- 1 with a remaining activity of $21 \%$.

Table 1. Inhibition screening of the selected ABMM compounds against ALDH1A1, ALDH1A3 and ALDH3A1. Enzyme activity was measured with hexanal (ALDH1A1 and ALDH1A3) or 4-NBA (ALDH3A1). Experimental values are shown as the mean \pm standard error (SE). ND: Not Determined.



Since ABMM-15 and ABMM-16 were the most promising compounds regarding an ALDH1A3 selective inhibition, a time-dependent inhibition assay was performed in order to study the possibility of a slow binding. Hence, each compound was pre-incubated for $20 \mathrm{~min}$ as opposed to the usual $5 \mathrm{~min}$ before initiating the reaction. No significant differences were observed, as shown in Table 2.

Table 2. Results of the inhibition screening after 5 and 20 min of pre-incubation for ALDH1A3 at $250 \mu \mathrm{M}$ hexanal.

\begin{tabular}{ccc}
\hline \multicolumn{3}{c}{ ALDH1A3 Remaining Activity \pm SE (\%) at $\mathbf{1 0} \boldsymbol{\mu M}$ Compound } \\
\hline Pre-Incubation & $\mathbf{5}$ in & $\mathbf{2 0 ~}$ min \\
\hline ABMM-15 & $12.35 \pm 0.72$ & $13.10 \pm 4.35$ \\
ABMM-16 & $19.22 \pm 0.51$ & $18.88 \pm 1.81$ \\
\hline
\end{tabular}

Following these findings, we decided to explore the structure-activity relationships (SAR) for the ALDH1A3 selectivity by ABMMs. Both compounds ABMM-15 and ABMM-16 have a methyloxy (- $\left.\mathrm{CH}_{2} \mathrm{O}-\right)$ group as a linker between the two benzene rings, while the linker in all other tested compounds is an ester group. This structural difference seemed to contribute to a remarkable difference in the inhibitory activity. For example, ABMM-2 and ABMM-1 share a structural similarity with ABMM-15 and ABMM-16, respectively, but have an ester linker instead of a methyloxy, which provided a much higher remaining activity (94\% of ABMM-2 vs. $0.14 \%$ of ABMM-15, and $21 \%$ of ABMM- 1 vs. $4.27 \%$ of ABMM-16). This finding highlights the importance of the methyloxy linkers in the inhibitory binding with the ALDH1A3 active site. In addition, the aromatic substitution seemed to have an effect on the inhibitory activity. For example, ABMM-16 is structurally different from ABMM-15 by having a methoxy group at a position meta to the aldehyde, which provided a higher remaining activity ( $0.14 \%$ vs. $4.27 \%)$. However, ABMM-1 has 
an extra methoxy group when compared to ABMM-2, yet it provided a lower remaining activity (21\% vs. 94\%). Unexpectedly, ABMM-18 has two methoxy groups at both positions meta to the aldehyde group, but it resulted in $16 \%$ of the remaining activity, which is lower than both ABMM-1 and ABMM-2.

An esterase activity has been described for the ALDH1A and ALDH3 subfamilies to a certain extent, in addition to the dehydrogenase activity. As some of the compounds have an ester linker and show no inhibitory activity on ALDH1A3, they could act as substrates, either for the aldehyde or for the ester group [36-38].

None of the compounds seemed to cause a significant inhibition of ALDH3A1 activity and thus they were not considered for further characterization. Moreover, some compounds, such as ABMM-2 and ABMM-15, showed a remaining activity higher than $100 \%$ for ALDH3A1, suggesting a potential substrate activity. In fact, the structures appear to be in a good agreement with the preferred type of aldehyde substrate for the ALDH3A1 pocket, as they are small aromatic aldehydes.

\subsection{Determination of Half-Maximal Inhibitory Concentrations $\left(I_{50}\right)$}

The $\mathrm{IC}_{50}$ values were calculated for compounds ABMM-15 and ABMM-16 as the best fits for ALDH1A3, with the results shown in Figure 2. Experiments for both compounds were performed at a saturating concentration of hexanal and resulted in $\mathrm{IC}_{50}$ values of $0.23 \pm 0.05 \mu \mathrm{M}$ and $1.29 \pm 0.10 \mu \mathrm{M}$ for ABMM-15 and ABMM-16, respectively.
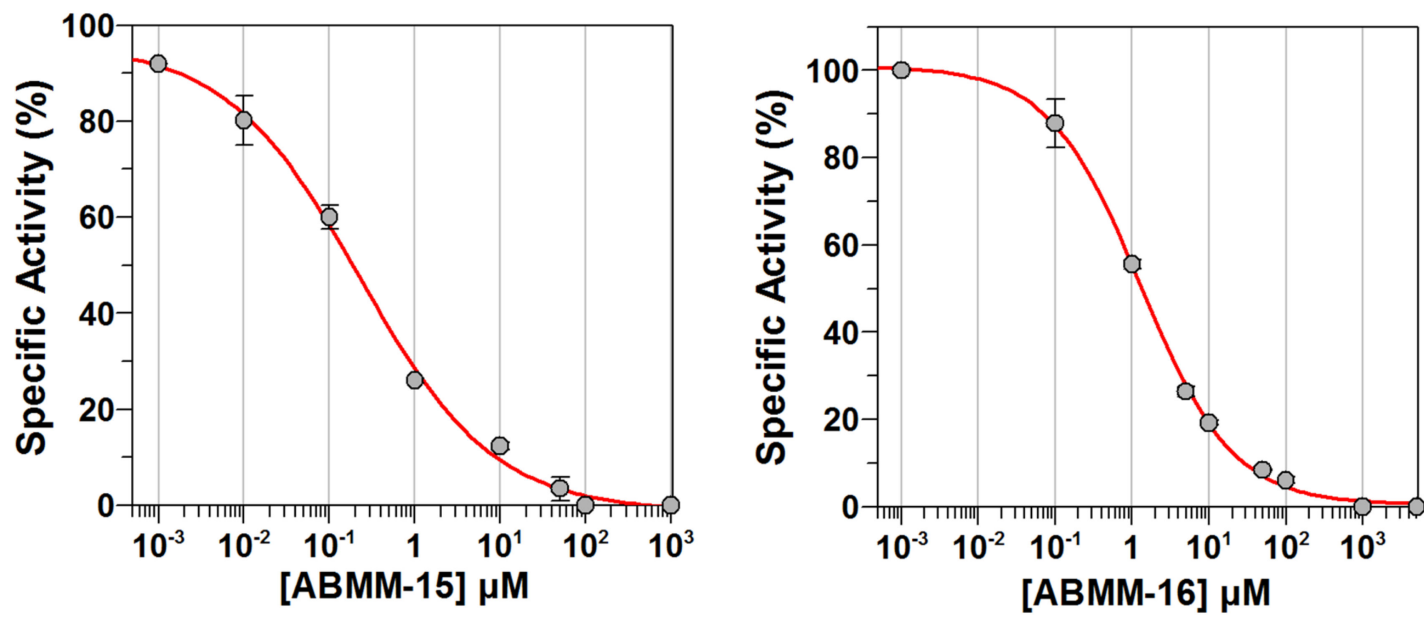

Figure 2. Representative sigmoidal curves to calculate the $\mathrm{IC}_{50}$ values of ABMM-15 (left) and ABMM-16 (right) against ALDH1A3 at a saturating concentration of hexanal $(250 \mu \mathrm{M})$. The percentage of specific activity is plotted against the logarithm of inhibitor concentration. Experimental values are shown as the mean $\pm \mathrm{SE}$ of duplicate experiments.

\subsection{Cytotoxicity Experiments}

NSCLC cell lines, including A549 and H1299, were chosen because of their wellknown expression level of ALDH isoforms, where it has been proven that A549 is highly expressing ALDH1A1 and ALDH3A1, but with a lower level of ALDH1A3, while H1299 is deficient in these isoforms and other family members $[39,40]$. In addition, as these cancer cell lines are commonly used as in vitro model for exploring new therapeutics [40], the synthesized compounds were investigated on these cell-lines to determine their effect on cell survival using the MTT assay after 24 and $96 \mathrm{~h}$ of exposure. The results are shown in Table 3 for $96 \mathrm{~h}$ of exposure. The highest concentration used for the compounds was $60 \mu \mathrm{M}$ due to solubility issues in dimethylsulfoxide (DMSO), so that the final concentration of DMSO did not exceed the acceptable non-toxic concentration of $0.2 \%$. 
Table 3. The chemical composition of ABMM analogues with $\mathrm{IC}_{50}$ values against $\mathrm{A} 549$ and $\mathrm{H} 1299$ cells (following $96 \mathrm{~h}$ of exposure) and against the ALDH1A3 enzyme. ND: Not Determined.<smiles>[X]Oc1cc([R])cc([Y])c1</smiles>

\begin{tabular}{|c|c|c|c|c|c|c|c|c|c|}
\hline \multirow[t]{2}{*}{ Compound } & \multirow[t]{2}{*}{$\begin{array}{c}\text { (O) Position } \\
\text { Relative To (Y) }\end{array}$} & \multirow[t]{2}{*}{ R1 } & \multirow[t]{2}{*}{$\mathbf{R} 2$} & \multirow[t]{2}{*}{ R3 } & \multirow[t]{2}{*}{$X$} & \multirow[t]{2}{*}{$\mathbf{Y}$} & \multicolumn{2}{|c|}{$\begin{array}{c}\text { Toxicity } \\
\left(\mathrm{IC}_{50}(\mu \mathrm{M}) \pm \mathrm{SE}\right)\end{array}$} & \multirow[t]{2}{*}{$\begin{array}{c}\mathrm{IC}_{50}(\mu \mathrm{M}) \pm \mathrm{SE} \\
\text { ALDH1A3 }\end{array}$} \\
\hline & & & & & & & A549 & H1299 & \\
\hline ABMM-1 & para & $\mathrm{Cl}$ & $\mathrm{OCH}_{3}$ & $\mathrm{H}$ & $\mathrm{C}=\mathrm{O}$ & $\mathrm{CHO}$ & $>60$ & $>60$ & ND \\
\hline ABMM-2 & para & $\mathrm{Cl}$ & $\mathrm{H}$ & $\mathrm{H}$ & $\mathrm{C}=\mathrm{O}$ & $\mathrm{CHO}$ & $>60$ & $>60$ & ND \\
\hline ABMM-3 & para & $\mathrm{F}$ & $\mathrm{H}$ & $\mathrm{H}$ & $\mathrm{C}=\mathrm{O}$ & $\mathrm{CHO}$ & $>60$ & $>60$ & ND \\
\hline ABMM-4 & para & $\mathrm{NO}_{2}$ & $\mathrm{H}$ & $\mathrm{H}$ & $\mathrm{C}=\mathrm{O}$ & $\mathrm{CHO}$ & ND & ND & ND \\
\hline ABMM-5 & para & $\mathrm{NO}_{2}$ & $\mathrm{OCH}_{3}$ & $\mathrm{H}$ & $\mathrm{C}=\mathrm{O}$ & $\mathrm{CHO}$ & ND & ND & ND \\
\hline ABMM-6 & para & $\mathrm{F}$ & $\mathrm{OCH}_{3}$ & $\mathrm{H}$ & $\mathrm{C}=\mathrm{O}$ & $\mathrm{CH}=\mathrm{CHCHO}$ & $>60$ & $14 \pm 2$ & ND \\
\hline ABMM-15 & para & $\mathrm{Cl}$ & $\mathrm{H}$ & $\mathrm{H}$ & $\mathrm{CH}_{2}$ & $\mathrm{CHO}$ & $>60$ & $>60$ & $0.23 \pm 0.05$ \\
\hline ABMM-16 & para & $\mathrm{Cl}$ & $\mathrm{OCH}_{3}$ & $\mathrm{H}$ & $\mathrm{CH}_{2}$ & $\mathrm{CHO}$ & $>60$ & $>60$ & $1.29 \pm 0.10$ \\
\hline ABMM-17 & meta & $\mathrm{Cl}$ & $\mathrm{H}$ & - & $\mathrm{C}=\mathrm{O}$ & $\mathrm{CHO}$ & $>60$ & $56 \pm 2.65$ & ND \\
\hline ABMM-18 & para & $\mathrm{F}$ & $\mathrm{OCH}_{3}$ & $\mathrm{OCH}_{3}$ & $\mathrm{C}=\mathrm{O}$ & $\mathrm{CHO}$ & $>60$ & $>60$ & ND \\
\hline ABMM-19 & para & $\mathrm{F}$ & $\mathrm{OCH}_{3}$ & $\mathrm{H}$ & $\mathrm{C}=\mathrm{O}$ & $\mathrm{CH}=\mathrm{CHCH}_{2} \mathrm{OH}$ & $>60$ & $46.33 \pm 4.48$ & ND \\
\hline ABMM-23 & para & $\mathrm{F}$ & $\mathrm{OCH}_{3}$ & $\mathrm{OCH}_{3}$ & $\mathrm{C}=\mathrm{O}$ & $\mathrm{CH} 2 \mathrm{OH}$ & $51 \pm 8$ & $>60$ & ND \\
\hline ABMM-24 & para & $\mathrm{Br}$ & $\mathrm{OCH}_{3}$ & $\mathrm{H}$ & $\mathrm{CH}_{2}$ & $\mathrm{CH}=\mathrm{CHCHO}$ & $>60$ & $13.67 \pm 1.67$ & ND \\
\hline ABMM-25 & para & $\mathrm{Br}$ & $\mathrm{OCH}_{3}$ & $\mathrm{H}$ & $\mathrm{CH}_{2}$ & $\mathrm{CH}=\mathrm{CHCH}_{2} \mathrm{OH}$ & $>60$ & $>60$ & ND \\
\hline ABMM-26 & para & $\mathrm{Br}$ & $\mathrm{OCH}_{3}$ & $\mathrm{H}$ & $\mathrm{CH}_{2}$ & $\mathrm{CH}=\mathrm{CHCOOH}$ & $>60$ & $>60$ & ND \\
\hline ABMM-27 & para & $\mathrm{F}$ & $\mathrm{OCH}_{3}$ & $\mathrm{H}$ & $\mathrm{C}=\mathrm{O}$ & $\mathrm{CH}=\mathrm{CHCOOH}$ & $>60$ & $>60$ & ND \\
\hline ABMM-28 & para & $\mathrm{CH}_{2} \mathrm{Cl}$ & $\mathrm{OCH}_{3}$ & $\mathrm{H}$ & $\mathrm{C}=\mathrm{O}$ & $\mathrm{CHO}$ & $50 \pm 1$ & $37.5 \pm 1.5$ & ND \\
\hline ABMM-32 & para & $\mathrm{CH}_{2} \mathrm{Cl}$ & $\mathrm{H}$ & $\mathrm{H}$ & $\mathrm{C}=\mathrm{O}$ & $\mathrm{CHO}$ & $51 \pm 5$ & $13 \pm 2.08$ & ND \\
\hline ABMM-33 & para & $\mathrm{NO}_{2}$ & $\mathrm{OCH}_{3}$ & $\mathrm{H}$ & $\mathrm{C}=\mathrm{O}$ & $\mathrm{CH}=\mathrm{CHCHO}$ & $>60$ & $35.33 \pm 1.76$ & ND \\
\hline ABMM-34 & ortho & $\mathrm{Cl}^{2}$ & $\mathrm{H}$ & $\mathrm{H}$ & $\mathrm{C}=\mathrm{O}$ & $\mathrm{CHO}$ & $>60$ & $>60$ & ND \\
\hline ABMM-35 & para & $\mathrm{Cl}$ & $\mathrm{H}$ & $\mathrm{H}$ & $\mathrm{C}=\mathrm{O}$ & $\mathrm{CH}_{2} \mathrm{OH}$ & $>60$ & $>60$ & ND \\
\hline
\end{tabular}

The ALDH3A1-expressing A549 cells exposed to ABMM-15 and ABMM-16 did not seem to be affected by exposure to these ALDH-affinic compounds. A possible explanation might be that these compounds are detoxified via conversion to their corresponding carboxylic acids.

In contrast to their effect on A549 cells, some other compounds showed a considerable toxicity on H1299 cells, including ABMM-6, ABMM-24, ABMM-28, ABMM-32 and ABMM-33. This may be related to the fact that A549 cells express high levels of ALDHs, which may be involved in the compound detoxification. Compounds ABMM-6, ABMM-24 and ABMM-33 are derivatives of coniferyl aldehyde, which contains a cinnamaldehyde nucleus (Figure 3). Cinnamaldehyde has been found to be cytotoxic on several cancer cell lines, such as leukemia K562 [41] and breast cancer MCF-7 cells [42]. Furthermore, cinnamaldehyde has been found to be a promising adjuvant candidate in combination with 5-fluorouracil and oxaliplatin against colorectal carcinoma [43], and to enhance the apoptosis induced by hyperthermia against the A549 cells [44] and by doxorubicin on glioblastoma cells (U87MG) [45]. This cytotoxicity of cinnamaldehyde may be due to the presence of an electrophilic Michael acceptor ( $\alpha, \beta$-unsaturated aldehyde) pharmacophore, which has been anticipated to provide this scaffold with a potential anticancer activity [46]. However, coniferyl aldehyde has not yet been reported to be cytotoxic and has been found non-toxic on MCF-7 and NCI-H187 cell lines [47]. In this study, the synthesized coniferyl aldehyde derivatives have an extended benzene ring linked to a hydroxyl group by either an ester group (as in ABMM-6) or a methyloxy group (as in ABMM-24), with no significant difference in their cytotoxicity according to their $\mathrm{IC}_{50}$ values of 14.0 and $13.7 \mu \mathrm{M}$, 
respectively. This elongation by an extra benzene ring seemed to play an important role in the cytotoxicity of the compounds. In addition, all these molecules share the aldehyde functionality, which also seemed to participate in the cytotoxicity. For example, when the aldehyde group in ABMM-24 was replaced by an alcohol (e.g., ABMM-25) or by a carboxylic acid (e.g., ABMM-26), the cytotoxicity was significantly reduced.<smiles>COc1cc(/C=C/C=O)ccc1OC(=O)c1ccc(F)cc1</smiles>

ABMM-6<smiles>COc1cc(/C=C/C=O)ccc1O</smiles><smiles>O=C/C=C/c1ccccc1</smiles><smiles>COc1cc(/C=C/C=O)ccc1OC(=O)c1ccc([N+](=O)[O-])cc1</smiles>

ABMM-33

Figure 3. Chemical structures of selected compounds.

Compounds ABMM-28 and ABMM-32 have similar chemical structures to ABMM-1 and ABMM-2, respectively, but with a $p$-chloromethyl group instead of chlorine. Since both ABMM-1 and ABMM-2 showed no significant toxicity on H1299 cells, the presence of chloromethyl in both ABMM-28 and ABMM-32 seemed to be important for the compound cytotoxicity, possibly acting as an alkylating moiety. Interestingly, compounds ABMM-15 and ABMM-16 showed no significant toxicity on either cell lines. Therefore, compounds ABMM-15 and ABMM-16 are worth investigating in combination therapies with anticancer drugs, such as doxorubicin and paclitaxel, where the inhibition of ALDH has been found to reduce chemoresistance in breast cancer cells [48].

Compound ABMM-23, which is an alcohol version of compound ABMM-18, is the only compound that showed a higher toxicity on $\mathrm{A} 549$ cells $\left(\mathrm{IC}_{50}=51.0 \mu \mathrm{M}\right)$ than on $\mathrm{H} 1299$ cells $\left(\mathrm{IC}_{50}>60 \mu \mathrm{M}\right)$, when compared with compound ABMM-18, which showed no toxicity on either cell line at the maximum concentration of $60 \mu \mathrm{M}$. This can be explained by the fact that ABMM-23 did not act as a substrate for ALDHs, while ABMM-18 might have had a mixed activity of both substrate and inhibitor.

\subsection{In Silico Study}

Docking studies were performed on some selected compounds of the series, employing Glide program (Maestro, Schrodinger) with a Standard Precision (PS) scoring function. The structures of three proteins (ALDH1A1, ALDH1A3 and ALDH3A1) were downloaded from the protein data (see the materials and methods for details). These docking studies were originally planned to better understand the potential binding of ABMM-15 and ABMM-16 to the ALDH1A3 binding site, in comparison to their binding to ALDH1A1 and ALDH3A1 binding sites. To compare the results with other ABMM compounds, three more compounds (ABMM-1, ABMM-2 and ABMM-18), which showed reasonable biological activities, were also selected for the docking studies to the three ALDH isoforms. The results are shown below in Figures 4-6.

As depicted in Figure 4, both ABMM-1 and ABMM-2 participated in H-bonding interactions with catalytic C302 of the ALDH1A1 binding site; however, the placement of the $p$-chlorophenyl ring seemed to be marginally different in both cases. The $p$-chlorophenyl ring of ABMM-1 was involved in multiple hydrophobic contacts with M175, W178, C303, V460 and F466, whereas the $p$-chlorophenyl of ABMM-2 established hydrophobic contacts with M175, F171, C302 and C303 within the ALDH1A1 binding site. A greater no. of 
hydrophobic contacts of ABMM-1 correspond to the docking score of $-7.709 \mathrm{kcal} / \mathrm{mol}$ (Table 4). The interactions of ABMM-2 with C302, C303 and F171 are predicted to be crucial, which may contribute to an increase in binding affinity towards the ALDH1A1 improved [S]et saturation of ABMM-2 over ABMM-1. The central benzaldehyde core of both ABMM-1 and ABMM-2 formed face-to-face pi-pi stacking with Y297. On comparison of ABMM-1 and ABMM-2 with the dihydropurine-based co-crystallized inhibitor of ALDH1A1, the co-crystallized inhibitor also depicted van der Waals interactions with F171, Y297, C302 and C303 (Figure 7A). The central benzaldehyde core of ABMM-15 oriented oppositely compared to ABMM-1 and ABMM-2 within the ALDH1A1 binding site and did not show any H-bond contacts. The hydrophobic interactions with F171, V174, M175 and F466 were constituted by ABMM-15, followed by H-bond contact with N170 and halogen bond formation with D122. The presence of these two additional interactions (H-bond and halogen) signifies the improved activity of ABMM-15 over ABMM- 1 and ABMM-2. The best compound of the series (ABMM-16) was found to be in complete agreement with the highest docking score of $-8.157 \mathrm{kcal} / \mathrm{mol}$. The $p$-chlorophenyl moiety of ABMM-16 established hydrophobic contacts with M175, W178, C303, V460 and F466, while its benzaldehyde core was involved in face-to-face pi-pi stacking with Y297. Apart from hydrophobic contacts, the methoxy group and methoxy linker of ABMM-2 formed a couple of H-bonds with C302, which may contribute to the enrichment in the binding affinity of ABMM-16 over other compounds. The presence of the methyloxy linker in place of the ester linker supported a favorable binding disposition. ABMM-18 formed a relatively lesser no. of $\mathrm{H}$-bond and hydrophobic interactions within the ALDH1A1 binding pocket, which corresponds to its poor binding affinity and docking score $(-6.193 \mathrm{kcal} / \mathrm{mol})$.

Table 4. Docking scores (kcal/mol) for compounds ABMM-1, 2, 15, 16 and 18, against the three ALDH isoforms (ALDH1A1, 1A3 and 3A1).

\begin{tabular}{cccc}
\hline & \multicolumn{3}{c}{ Docking Scores (kcal/mol) } \\
\hline & ALDH1A1 & ALDH1A3 & ALDH3A1 \\
\hline ABMM-1 & -7.709 & -7.717 & -7.238 \\
ABMM-2 & -7.104 & -7.844 & -5.826 \\
ABMM-15 & -7.246 & -7.804 & -6.707 \\
ABMM-16 & -8.157 & -8.306 & -7.029 \\
ABMM-18 & -6.193 & -7.753 & -7.402 \\
\hline
\end{tabular}

Figure 5 shows the docking poses of the ABMM compounds within the ALDH1A3 binding site. The p-halogen rings of ABMM-1, ABMM-2, ABMM-16 and ABMM-18 were accommodated into the hydrophobic cavity, whereas their benzaldehyde cores were placed at the entrance of the ALDH1A3 binding site. The $p$-chlorophenyl ring of ABMM- 1 constituted hydrophobic contacts with F182, C313, C314 and L471, while the methoxy group of its benzaldehyde core facilitated hydrophobic contacts with W189 and L189. Furthermore, the aldehyde group of ABMM-1 formed a H-bond with R139. A similar H-bond and hydrophobic interaction pattern was observed for ABMM-2, ABMM-16 and ABMM-18; however, ABMM-18 demonstrated a lesser no. of $\mathrm{H}$-bond and hydrophobic contacts. In particular, the presence of methoxy linker on the second-best compound of the series, ABMM-16, favored the binding to ALDH1A3, establishing hydrophobic contacts with L185 and L489. The best compound of the series, ABMM-15, was oriented oppositely relative to other compounds. The aldehyde of ABMM-15 constituted H-bond contacts with the C302, C303 and T315. These H-bond interactions are believed to crucially contribute to the binding affinity with the target, as the co-crystallized substrate of ALDH1A3 (RA) also displayed a similar interaction with C314 and T315 (Figure 7B). The central benzaldehyde core was involved in pi-pi interactions with F182 and L471, whereas the $p$-chlorophenyl ring of ABMM-1 implicated halogen bond interaction with A473 and hydrophobic contacts with L185 and L489. Despite the docking score of ABMM-16 (-8.306 kcal/mol) being relatively higher than ABMM-1 ( $-7.804 \mathrm{kcal} / \mathrm{mol} /)$, the presence of crucial $\mathrm{H}$-bond contacts between 
ABMM-1 and ALDH1A3 hydrophobic cavity is envisioned to contribute to the improved binding affinity towards ALDH1A3.

A

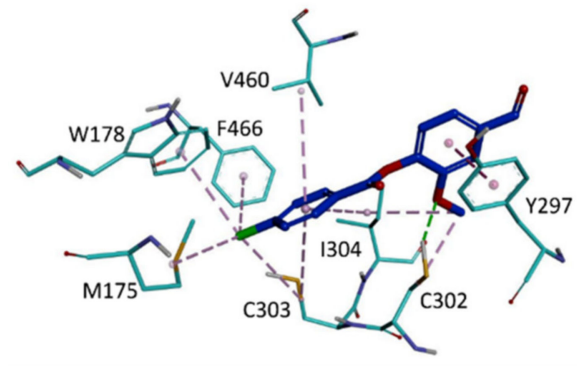

B

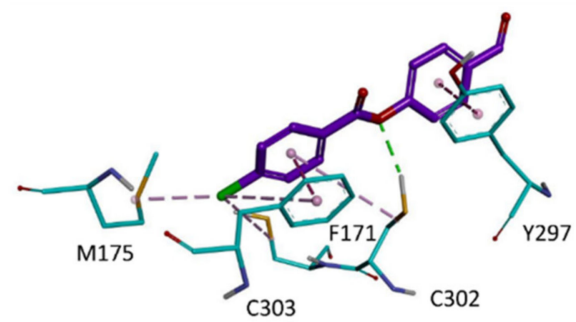

C

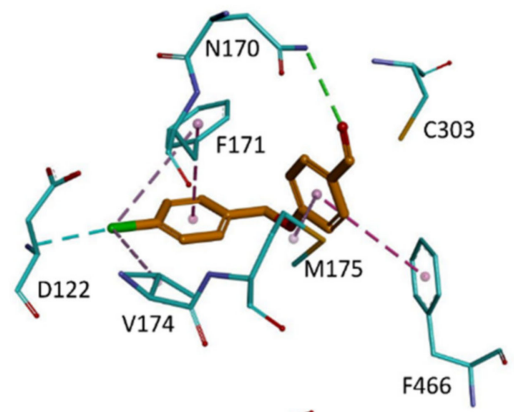

D

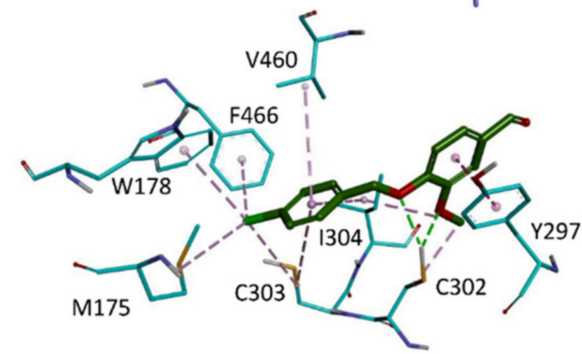

$\mathbf{E}$

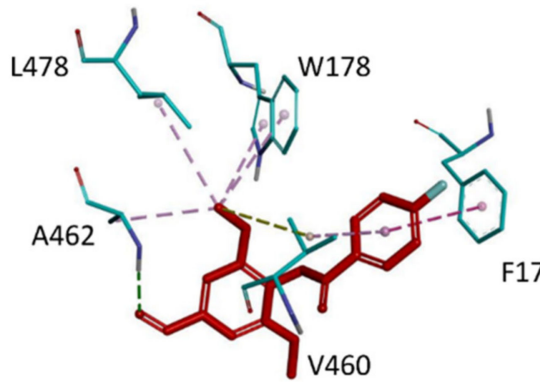

Interactions
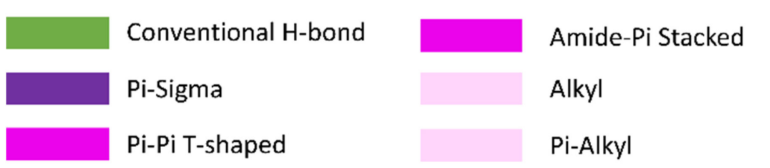
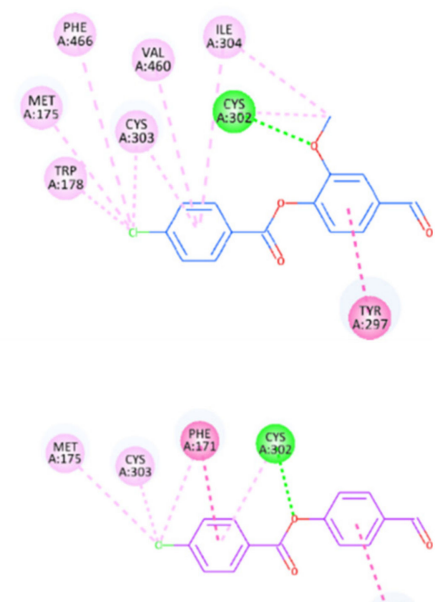

(2019)
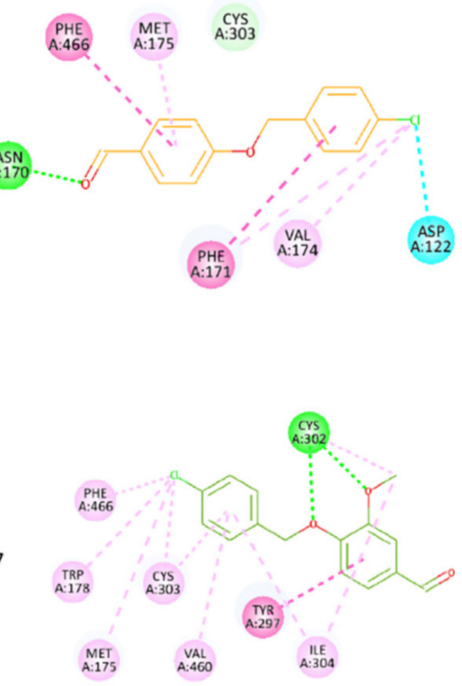

Figure 4. Molecular docking of: (A) ABMM-1 (blue), (B) ABMM-2 (purple), (C) ABMM-15 (orange), (D) ABMM-16 (green) and (E) ABMM-18 (red) into the ALDH1A1 binding site (cyan-colored residues). 
A
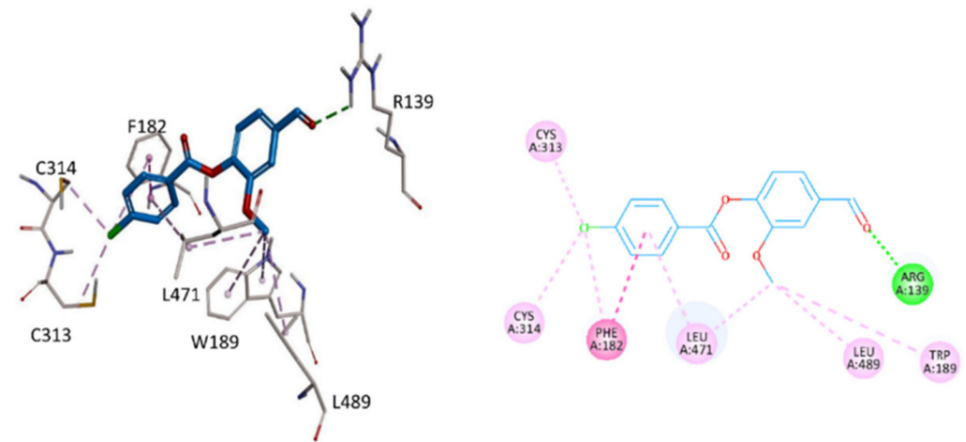

B

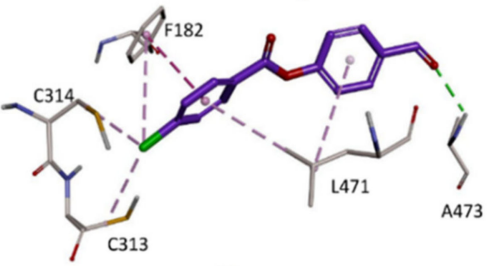

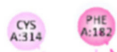

C

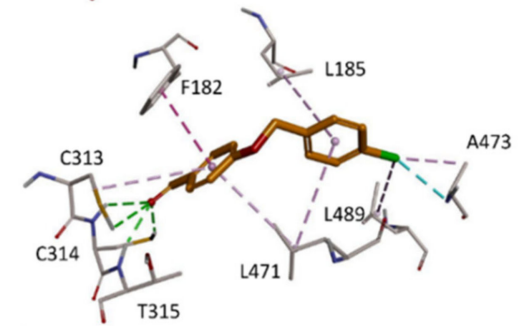

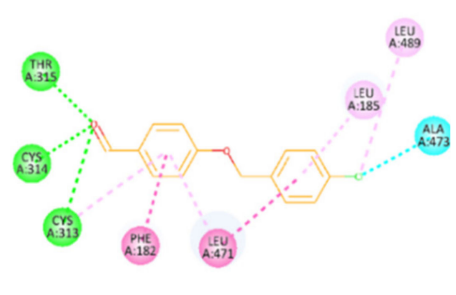

D

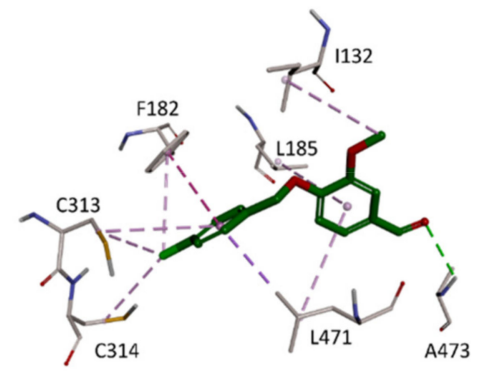

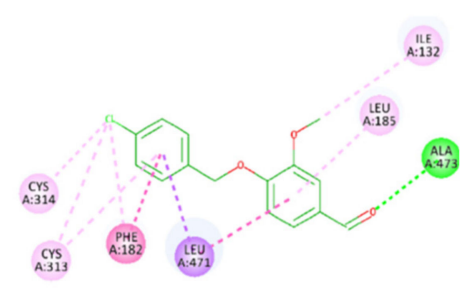

E

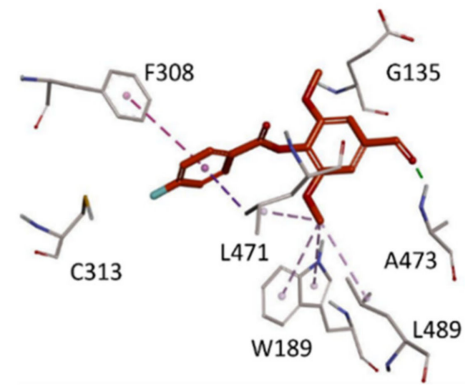





Interactions
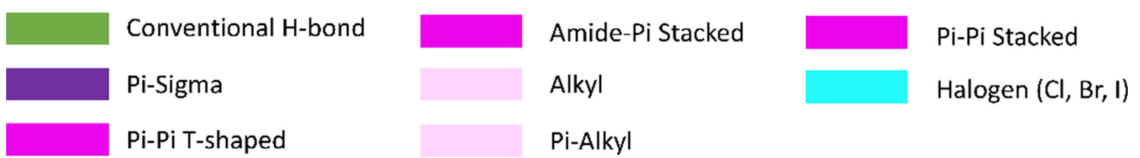

Figure 5. Molecular docking of: (A) ABMM-1 (cyan), (B) ABMM-2 (purple), (C) ABMM-15 (orange), (D) ABMM-16 (green) and (E) ABMM-18 (red) into the ALDH1A3 binding site (gray-colored residues). 
A
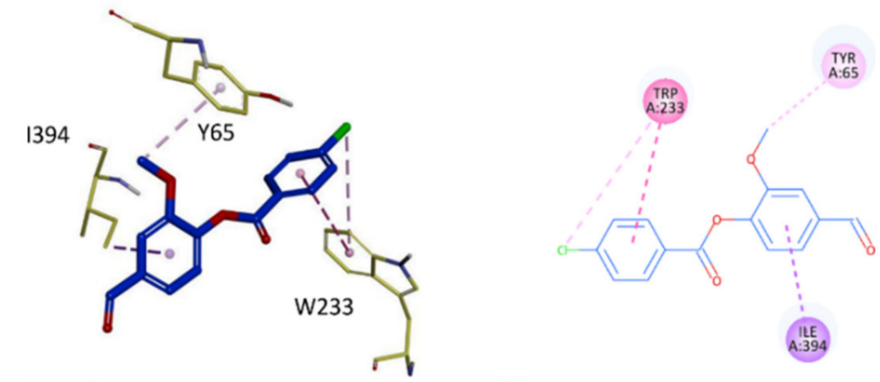

(11:396

B

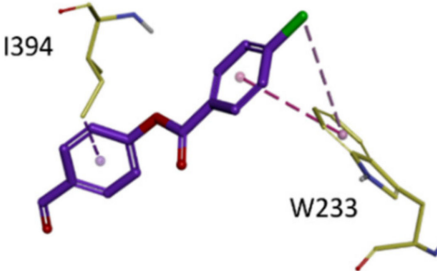

TRP

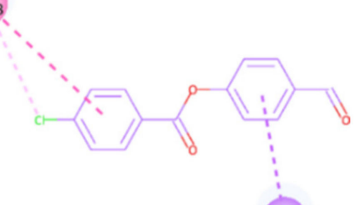

(11:89

C
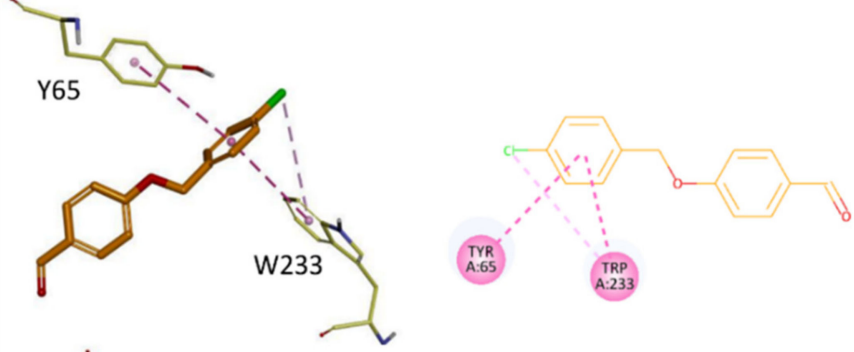

D
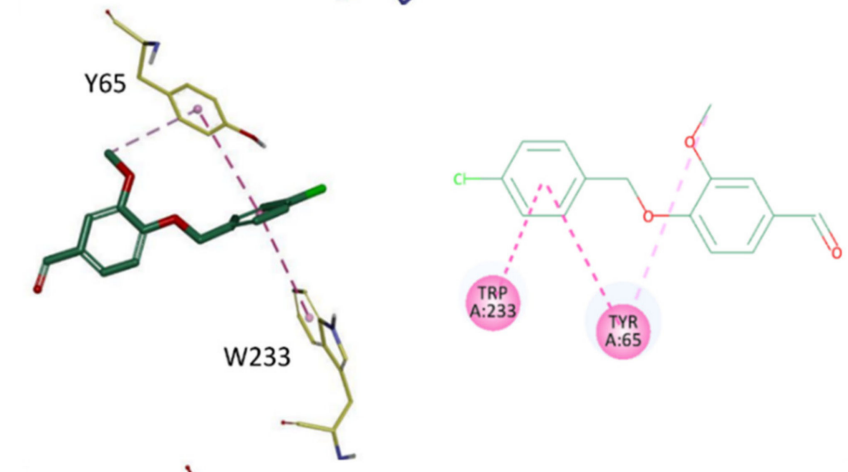

E


Interactions
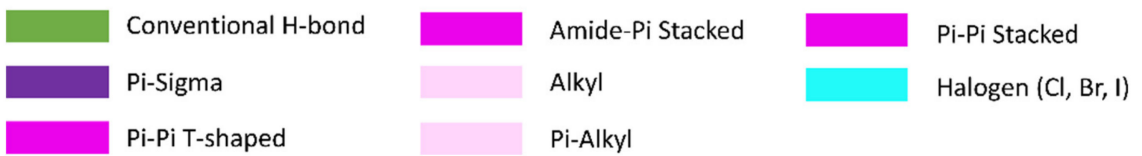

Pi-Alkyl

Figure 6. Molecular docking of: (A) ABMM-1 (blue), (B) ABMM-2 (purple), (C) ABMM-15 (orange), (D) ABMM-16 (green) and (E) ABMM-18 (red) into the ALDH3A1 binding site (yellow-colored residues). 



Figure 7. Superimposition of (A) co-crystallized inhibitor (green) of ALDH1A1 (cyan residues) and ABMM-16 (yellow), (B) substrate (RA, green) of ALDH1A3 (gray residues) and ABMM-15 (orange) and (C) co-crystallized inhibitor (cyan) of ALDH3A1 (yellow residues) and ABMM-18 (Red). Only the interactions of co-crystallized inhibitors/substrate are shown for clarity.

As shown in Figure 6, compounds ABMM-1, ABMM-2, ABMM-15, ABMM-16 and ABMM-18 presented similar binding modes within the ALDH3A1 binding site. The p-halogen ring of these compounds established at least one pi-pi stacking interaction with W233. All these compounds displayed a poor interaction profile within the ALDH3A1 binding site compared to ALDH1A1 and ALDH1A3, which further resemble the docking scores and weak binding affinities. Only ABMM-18 was able to demonstrate multiple van der Waals contacts (Y65, Y115, W233, M237 and I391), which was also partly shown by the nitrophenylamine-based co-crystallized inhibitor of ALDH3A1 (Y65, Y115) (Figure 7C), but it still lacked ALDH3A1 inhibition.

As shown in Figure 7, the three most active compounds (ABMM-16 for ALDH1A1, ABMM-15 for ALDH1A3 and ABMM-18 for ALDH3A1) were compared with the crystallographic pose of the bound inhibitor/substrate from their respective proteins. Figure 7A depicts the crystallographic binding mode of the dihydropurine-based inhibitor, which formed crucial face-to-face pi-pi stacking with Y297. This interaction is identically formed by the benzaldehyde core of ABMM-16. One of the oxo from the dihydropurine-based co-crystallized inhibitor of ALDH1A1 established an important H-bond with C302, which is also shown by the methoxy-group of the ABMM-16. Hydrophobic interactions with M175, W178, C303 and I304 were shared by both the co-crystallized inhibitor and ABMM-16. As shown in Figure 7B, the co-crystallized substrate of ALDH1A3, RA and ABMM-15 were superimposed. RA constituted H-bond interactions with C314 and T315 in the 
ALDH1A3 binding site, similar to ABMM-15 (Figure 5C). The hydrophobic moiety of RA formed van der Waals contacts with L185, L489 and L471, which were also constituted by ADMM-15 within the ALDH1A3 binding site. Figure 7C displays the binding orientation of nitrophenylamine-based co-crystallized inhibitor, superimposed with ABMM-18 within the ALDH3A1 binding site. The co-crystallized inhibitor demonstrated important $\mathrm{H}$-bond contacts with V114, C243 and V244 that are completely missing in ABMM-18, probably satisfying the poor inhibition profile of ABMM-18 against ALDH3A1. Two pi-pi interactions were found to be shared by both the co-crystallized inhibitor and ABMM-18, which may not be sufficient for ABMM-18 to effectively contribute to the increase in binding affinity; thus, ABMM-18 requires further structure-based hit optimization.

\section{Materials and Methods}

All materials and reagents were used as received with no further purification. 4-hydroxybenzaldehyde, syringaldehyde, coniferyl aldehyde, 4-fluorobenzoyl chloride, 4-chlorobenzoyl chloride, 4-NBA, hexanal, HEPES, EDTA, DTT, $\mathrm{MgCl}_{2}$, Tris- $\mathrm{HCl}$, MTT and 4-nitorobenzoyl chloride were purchased from (Sigma, Dorset, UK); $\mathrm{NAD}^{+}, \mathrm{NADH}$, $\mathrm{NADP}^{+}$and NADPH were purchased from (Apollo Scientific, Bredbury, UK); 3-hydroxybenzaldehyde, 2-hydroxybenzaldehyde, Vanillin, and 4-(chloromethyl)benzoyl chloride were purchased from (Acros Organics, Belgium, USA); A549 and H1299 human NSCLC cell lines were purchased from ATCC with LOT number 70018877 and 70008730 , respectively; PBS, RPMI-1640 medium, fetal bovine serum (FBS) and L-glutamine were purchased from (Euroclone, Pero, Italy); DMSO was purchased from TEDIA (USA). Chemical reactions were monitored by analytical thin layer chromatography using Merck 9385 silica gel 60 F254 aluminum-backed plates through visualizing the spotted plates under ultraviolet (UV) at 254 and $366 \mathrm{~nm}$. Intermediates and final products were purified by column chromatography using silica gel (pore size $60 \AA, 40-63 \mu \mathrm{m}$ particle size). Proton and carbon NMR were analyzed for all intermediates and final products on Bruker AMX400 (400 MHz and $300 \mathrm{MHz}$ ) nuclear magnetic resonance spectrometer. Chemical shifts were reported in parts per million $(\delta, \mathrm{ppm})$ downfield from internal TMS. Coupling constants (J) were expressed in Hertz $(\mathrm{Hz})$. High-resolution mass spectra were obtained by the Engineering and Physical Sciences Research Council (EPSRC) mass spectrometry service, Swansea, UK. The spectra for the products can be found in the Supplementary Materials. Chemical structures were drawn using ChemDraw (version 18.0.0231). Melting points were measured with a Gallenkamp melting point apparatus. Dose-response curves were generated using the GraphPad Prism 7 Software; optical densities were then measured on a SynergyHTX ${ }^{\circledR}$ spectrophotometer; $\mathrm{IC}_{50}$ values were calculated by non-linear fitting of the experimental data to a sigmoidal plot using GraFit 5.0 (Erithacus software); enzymatic activity was measured using a Cary Eclipse Varian fluorimeter.

\subsection{Chemistry}

3.1.1. General Procedure for the Synthesis of Compounds ABMM-1-6, 17, 18, 27, 28, 32-34

To a solution of the phenolic starting material (1.0 eq.) in $10 \mathrm{~mL}$ DMF, trimethylamine (2.0 eq.) was added, and the solution was stirred at room temperature for $30 \mathrm{~min}$. To the stirred solution, acid chloride (1.0 eq.) was added slowly dropwise or by portions, and the resulting solution was stirred at room temperature for one hour. After the reaction completion, $20 \mathrm{~mL}$ saturated aqueous solution of sodium carbonate was added portionwise. The resulting precipitate was filtered, dried and purified by either recrystallization or column chromatography, affording the desired product.

\subsubsection{General Procedure for the Synthesis of Compounds ABMM-15, 16, 24, 26}

To a solution of the phenolic starting material (1.0 eq.) and potassium carbonate (1.5 eq.) in $10 \mathrm{~mL} \mathrm{DMF}$, benzyl halide (1.0 eq.) was added, and the resulting solution was stirred overnight at $70{ }^{\circ} \mathrm{C}$. After the reaction was completed, volume of DMF was reduced by evaporation under vacuum. To the resulting solution, $20 \mathrm{~mL}$ water was added and the 
resulting precipitation was filtered, dried and recrystallized from ethanol, affording the desired product.

\subsubsection{General Procedure for the Synthesis of Compounds ABMM-19, 23, 25, 35}

The starting aldehyde (1.0 eq.) was dissolved in $10 \mathrm{~mL}$ absolute ethanol and stirred for $10 \mathrm{~min}$ in ice bath. $\mathrm{NaBH} 4$ (3.0 eq.) was then added slowly over a period of $10 \mathrm{~min}$. The reaction was followed by TLC and when completed, $10 \mathrm{~mL}$ of distilled water was added and the mixture was stirred at $0{ }^{\circ} \mathrm{C}$ for $10 \mathrm{~min}$. The product was then extracted by chloroform $(3 \times 20 \mathrm{~mL})$. The collected organic phase was dried over magnesium sulfate and filtered. The solvent was evaporated under vacuum, affording the desired product.

4-Formyl-2-methoxyphenyl 4-Chlorobenzoate (ABMM-1)

Off-white solid; $92 \%$ yield; mp $98-100{ }^{\circ} \mathrm{C} .{ }^{1} \mathrm{H}$ NMR $\left(400 \mathrm{MHz}, \mathrm{CDCl}_{3}\right) \delta 9.92(\mathrm{~s}, 1 \mathrm{H}$, CHO), 8.08 (d, $J=8.8 \mathrm{~Hz}, 2 \mathrm{H}, \mathrm{ArH}), 7.50-7.47(\mathrm{~m}, 1 \mathrm{H}, \mathrm{ArH}), 7.48-7.46(\mathrm{~m}, 1 \mathrm{H}, \mathrm{ArH}), 7.44$ $(\mathrm{d}, J=8.8 \mathrm{~Hz}, 2 \mathrm{H}, \mathrm{ArH}), 7.28(\mathrm{~d}, J=7.9 \mathrm{~Hz}, 1 \mathrm{H}), 3.82\left(\mathrm{~s}, 3 \mathrm{H}, \mathrm{CH}_{3}\right) .{ }^{13} \mathrm{C} \mathrm{NMR}(101 \mathrm{MHz}$, $\mathrm{CDCl}_{3}$ ) $\delta 191.05,163.34,152.13,145.00,140.46,135.40,131.78,129.05,127.30,124.79,123.51$, 110.92, 56.16. HRMS (ESI) calculated for $\mathrm{C}_{15} \mathrm{H}_{11} \mathrm{ClO}_{4}[\mathrm{M}+\mathrm{H}]^{+} 291.03459$, found 291.04347 .

\section{4-Formylphenyl 4-Chlorobenzoate (ABMM-2)}

White solid; $91 \%$ yield; mp 111-113 ${ }^{\circ} \mathrm{C} .{ }^{1} \mathrm{H}$ NMR $\left(400 \mathrm{MHz}, \mathrm{CDCl}_{3}\right) \delta 9.96(\mathrm{~s}, 1 \mathrm{H}$, CHO), $8.07(\mathrm{~d}, J=8.8 \mathrm{~Hz}, 2 \mathrm{H}, \mathrm{ArH}), 7.91(\mathrm{~d}, J=8.7 \mathrm{~Hz}, 2 \mathrm{H}, \mathrm{ArH}), 7.44(\mathrm{~d}, J=8.8 \mathrm{~Hz}, 2 \mathrm{H}$, ArH), $7.34(\mathrm{~d}, J=8.7 \mathrm{~Hz}, 2 \mathrm{H}, \mathrm{ArH}) .{ }^{13} \mathrm{C} \mathrm{NMR}\left(101 \mathrm{MHz}, \mathrm{CDCl}_{3}\right) \delta 190.89,163.69,155.45$, $140.68,134.22,131.65,131.32,129.15,127.37,122.48$. HRMS (ESI) calculated for $\mathrm{C}_{14} \mathrm{H}_{9} \mathrm{ClO}_{3}$ $[\mathrm{M}+\mathrm{H}]^{+}$261.02402, found 261.03153 .

\section{4-Formylphenyl 4-Fluorobenzoate (ABMM-3)}

White solid; $53 \%$ yield; $\mathrm{mp} 75-77^{\circ} \mathrm{C} .{ }^{1} \mathrm{H}$ NMR $\left(400 \mathrm{MHz}, \mathrm{CDCl}_{3}\right) \delta 10.03(\mathrm{~s}, 1 \mathrm{H}, \mathrm{CHO})$, $8.23(\mathrm{dd}, J=8.9,5.4 \mathrm{~Hz}, 2 \mathrm{H}, \mathrm{ArH}), 7.98(\mathrm{~d}, J=8.6 \mathrm{~Hz}, 2 \mathrm{H}, \mathrm{ArH}), 7.41(\mathrm{~d}, J=8.6 \mathrm{~Hz}, 2 \mathrm{H}$, ArH), $7.21(\mathrm{dd}, J=15.8,8.9 \mathrm{~Hz}, 2 \mathrm{H}, \mathrm{ArH}) .{ }^{13} \mathrm{C}$ NMR $\left(101 \mathrm{MHz}, \mathrm{CDCl}_{3}\right) \delta 191.06,169.05$ $(\mathrm{d}, J=246.9 \mathrm{~Hz}), 165.28,155.67,134.31,133.10(\mathrm{~d}, J=9.6 \mathrm{~Hz}), 131.45,125.31(\mathrm{~d}, J=3.2 \mathrm{~Hz})$, $122.64,116.26,(\mathrm{~d}, J=22.1 \mathrm{~Hz})$.

4-Formylphenyl 4-Nitrobenzoate (ABMM-4)

White solid; 85\% yield; mp 197-200 ${ }^{\circ} \mathrm{C} .{ }^{1} \mathrm{H}$ NMR $\left(400 \mathrm{MHz}, \mathrm{CDCl}_{3}\right) \delta 9.98(\mathrm{~s}, 1 \mathrm{H}$, $\mathrm{CHO}), 8.32(\mathrm{~s}, 4 \mathrm{H}, \mathrm{ArH}), 7.94(\mathrm{~d}, J=8.6 \mathrm{~Hz}, 2 \mathrm{H}, \mathrm{ArH}), 7.37(\mathrm{~d}, J=8.6 \mathrm{~Hz}, 2 \mathrm{H}, \mathrm{ArH})$. ${ }^{13} \mathrm{C}$ NMR $\left(101 \mathrm{MHz}, \mathrm{CDCl}_{3}\right) \delta 190.77,162.71,155.04,151.15,134.52,134.30,131.44,131.41$, 123.88, 122.33. HRMS (ESI) calculated for $\mathrm{C}_{14} \mathrm{H}_{9} \mathrm{NO}_{5}[\mathrm{M}+\mathrm{H}]^{+} 286.06372$, found 286.07122 .

4-Formyl-2-methoxyphenyl 4-Nitrobenzoate (ABMM-5)

White solid; 88\% yield; mp 174-176 ${ }^{\circ} \mathrm{C} .{ }^{1} \mathrm{H}$ NMR $\left(400 \mathrm{MHz}, \mathrm{CDCl}_{3}\right) \delta 9.93(\mathrm{~s}, 1 \mathrm{H}$, CHO), 8.34-8.29 (m, 4H, ArH), 7.51-7.47 (m, 2H, ArH), $7.31(\mathrm{~d}, J=7.8 \mathrm{~Hz}, 1 \mathrm{H}), 3.84(\mathrm{~s}, 3 \mathrm{H}$, $\left.\mathrm{CH}_{3}\right) .{ }^{13} \mathrm{C} \mathrm{NMR}\left(101 \mathrm{MHz}, \mathrm{CDCl}_{3}\right) \delta 190.94,162.33,151.92,151.06,144.56,135.68,134.25$, $131.54,124.75,123.79,123.34,111.01,56.19$.

(E)-2-Methoxy-4-(3-oxoprop-1-en-1-yl)phenyl 4-Fluorobenzoate (ABMM-6)

White solid; $82 \%$ yield; mp $118-120{ }^{\circ} \mathrm{C} .{ }^{1} \mathrm{H}$ NMR $\left(400 \mathrm{MHz}, \mathrm{CDCl}_{3}\right) \delta 9.65$ $(\mathrm{d}, J=7.6 \mathrm{~Hz}, 1 \mathrm{H}, \mathrm{CHO}), 8.16(\mathrm{dd}, J=9.0,5.4 \mathrm{~Hz}, 2 \mathrm{H}, \mathrm{ArH}), 7.41(\mathrm{~d}, J=15.9 \mathrm{~Hz}, 1 \mathrm{H}$, $\mathrm{CH}), 7.18-7.09(\mathrm{~m}, 5 \mathrm{H}, \mathrm{ArH}), 6.63(\mathrm{dd}, J=15.9,7.6 \mathrm{~Hz}, 1 \mathrm{H}, \mathrm{CH}), 3.80\left(\mathrm{~s}, 3 \mathrm{H}, \mathrm{CH}_{3}\right) .{ }^{13} \mathrm{C} \mathrm{NMR}$ $\left(101 \mathrm{MHz}, \mathrm{CDCl}_{3}\right) \delta 193.45,166.28(\mathrm{~d}, J=255.4 \mathrm{~Hz}), 163.46,151.86,151.81,142.35,133.09$, $133.07,132.98,128.83,125.25(\mathrm{~d}, J=3.0 \mathrm{~Hz}), 122.78(\mathrm{~d}, J=171.1 \mathrm{~Hz}), 115.86(\mathrm{~d}, J=22.1 \mathrm{~Hz})$, 111.49, 56.03. HRMS (ESI) calculated for $\mathrm{C}_{17} \mathrm{H}_{13} \mathrm{FO}_{4}[\mathrm{M}+\mathrm{H}]^{+} 301.07979$, found 301.08612 . 
4-((4-Chlorobenzyl)oxy)benzaldehyde (ABMM-15)

White solid; $88 \%$ yield; mp $69-71{ }^{\circ} \mathrm{C} .{ }^{1} \mathrm{H}$ NMR $\left(400 \mathrm{MHz}, \mathrm{CDCl}_{3}\right) \delta 9.82(\mathrm{~s}, 1 \mathrm{H}, \mathrm{CHO})$, $7.77(\mathrm{~d}, J=8.9 \mathrm{~Hz}, 2 \mathrm{H}, \mathrm{ArH}), 7.35-7.25(\mathrm{~m}, 4 \mathrm{H}, \mathrm{ArH}), 6.99(\mathrm{~d}, J=8.7 \mathrm{~Hz}, 2 \mathrm{H}, \mathrm{ArH}), 5.05$ $\left(\mathrm{s}, 2 \mathrm{H}, \mathrm{CH}_{2}\right) .{ }^{13} \mathrm{C}$ NMR $\left(101 \mathrm{MHz}, \mathrm{CDCl}_{3}\right) \delta 190.75,163.44,134.46,134.22,132.03,130.32$, $128.95,128.81,115.13,69.48$. HRMS (ESI) calculated for $\mathrm{C}_{14} \mathrm{H}_{11} \mathrm{ClO}_{2}[\mathrm{M}+\mathrm{H}]^{+} 247.04476$, found 246.05249 .

4-((4-Chlorobenzyl)oxy)-3-methoxybenzaldehyde (ABMM-16)

White solid; $86 \%$ yield; mp 77-80 ${ }^{\circ} \mathrm{C} .{ }^{1} \mathrm{H}$ NMR $\left(400 \mathrm{MHz}, \mathrm{CDCl}_{3}\right) \delta 9.78(\mathrm{~s}, 1 \mathrm{H}, \mathrm{CHO})$, $7.37(\mathrm{~d}, J=1.8 \mathrm{~Hz}, 1 \mathrm{H}, \mathrm{ArH}), 7.33(\mathrm{dd}, J=8.2,1.8 \mathrm{~Hz}, 1 \mathrm{H}, \mathrm{ArH}), 7.31-7.27(\mathrm{~m}, 4 \mathrm{H}, \mathrm{ArH})$, $6.89(\mathrm{~d}, J=8.2 \mathrm{~Hz}, 1 \mathrm{H}, \mathrm{ArH}), 5.13\left(\mathrm{~s}, 2 \mathrm{H}, \mathrm{CH}_{2}\right), 3.88\left(\mathrm{~s}, 3 \mathrm{H}, \mathrm{CH}_{3}\right) .{ }^{13} \mathrm{C} \mathrm{NMR}(101 \mathrm{MHz}$, $\left.\mathrm{CDCl}_{3}\right) \delta 190.88,157.44,134.67,133.22,130.20,128.96,128.60,126.50,112.43,109.46,70.14$, 56.08. HRMS (ESI) calculated for $\mathrm{C}_{15} \mathrm{H}_{13} \mathrm{ClO}_{3}[\mathrm{M}+\mathrm{H}]^{+}$277.05532, found 277.06171.

3-Formylphenyl 4-Fluorobenzoate (ABMM-17)

White solid; 85\% yield; mp 58-60 ${ }^{\circ} \mathrm{C} .{ }^{1} \mathrm{H}$ NMR $\left(400 \mathrm{MHz}, \mathrm{CDCl}_{3}\right) \delta 9.97(\mathrm{~s}, 1 \mathrm{H}, \mathrm{CHO})$, $8.16(\mathrm{dd}, J=9.0,5.4 \mathrm{~Hz}, 2 \mathrm{H}, \mathrm{ArH}), 7.74(\mathrm{ddd}, J=7.6,2.4,1.3 \mathrm{~Hz}, 1 \mathrm{H}, \mathrm{ArH}), 7.71-7.64(\mathrm{~m}, 1 \mathrm{H}$, ArH), $7.55(\mathrm{dd}, J=8.1,7.6 \mathrm{~Hz}, 1 \mathrm{H}, \mathrm{ArH}), 7.43(\mathrm{ddd}, J=8.1,2.4,1.1 \mathrm{~Hz}, 1 \mathrm{H}, \mathrm{ArH}), 7.14(\mathrm{dd}$, $J=9.0,8.5 \mathrm{~Hz}, 2 \mathrm{H}, \mathrm{ArH}) .{ }^{13} \mathrm{C} \mathrm{NMR}\left(101 \mathrm{MHz}, \mathrm{CDCl}_{3}\right) \delta 191.11,166.37(\mathrm{~d}, J=255.8 \mathrm{~Hz})$, $163.92,151.43,137.89,132.97,132.87,130.26,127.67(\mathrm{~d}, J=37.1 \mathrm{~Hz}), 125.26(\mathrm{~d}, J=3.0 \mathrm{~Hz})$, $122.40,115.98(\mathrm{~d}, J=22.1 \mathrm{~Hz})$. HRMS (ESI) calculated for $\mathrm{C}_{14} \mathrm{H}_{9} \mathrm{FO}_{3}[\mathrm{M}]^{+} 244.05357$, found 244.06335 .

4-Formyl-2,6-dimethoxyphenyl 4-Fluorobenzoate (ABMM-18)

White solid; $44 \%$ yield; mp $72-74{ }^{\circ} \mathrm{C} .{ }^{1} \mathrm{H}$ NMR $\left(400 \mathrm{MHz}, \mathrm{CDCl}_{3}\right) \delta 9.88(\mathrm{~s}, 1 \mathrm{H}, \mathrm{CHO})$, $8.18(\mathrm{dd}, J=9.0,5.4 \mathrm{~Hz}, 2 \mathrm{H}, \mathrm{ArH}), 7.16-7.08(\mathrm{~m}, 4 \mathrm{H}, \mathrm{ArH}), 3.83\left(\mathrm{~s}, 6 \mathrm{H}, \mathrm{OCH}_{3}\right) .{ }^{13} \mathrm{C} \mathrm{NMR}$ $\left(101 \mathrm{MHz}, \mathrm{CDCl}_{3}\right) \delta 191.07,166.27(\mathrm{~d}, J=255.2 \mathrm{~Hz}), 162.95,153.13,134.49,133.90,133.14$ $(\mathrm{d}, J=9.5 \mathrm{~Hz}), 125.14(\mathrm{~d}, J=3.0 \mathrm{~Hz}), 115.81(\mathrm{~d}, J=22.1 \mathrm{~Hz}), 106.14,56.42$. HRMS (ESI) calculated for $\mathrm{C}_{16} \mathrm{H}_{13} \mathrm{FO}_{5}[\mathrm{M}+\mathrm{H}]^{+}$305.07470, found 305.90508.

(E)-4-(3-Hydroxyprop-1-en-1-yl)-2-methoxyphenyl 4-Fluorobenzoate (ABMM-19)

White solid; $70 \%$ yield; $\mathrm{mp} 124-126^{\circ} \mathrm{C} .{ }^{1} \mathrm{H}$ NMR $\left(400 \mathrm{MHz}, \mathrm{CDCl}_{3}\right) \delta 8.16(\mathrm{dd}, J=9.0$, $5.4 \mathrm{~Hz}, 2 \mathrm{H}, \mathrm{ArH}), 7.11(\mathrm{t}, J=8.7 \mathrm{~Hz}, 2 \mathrm{H}, \mathrm{ArH}), 7.03(\mathrm{~d}, J=8.1 \mathrm{~Hz}, 1 \mathrm{H}, \mathrm{ArH}), 6.99-6.90$ $(\mathrm{m}, 2 \mathrm{H}, \mathrm{ArH}), 6.55(\mathrm{~d}, J=15.9 \mathrm{~Hz}, 1 \mathrm{H}, \mathrm{CH}), 6.28(\mathrm{dt}, J=15.9,5.7 \mathrm{~Hz}, 1 \mathrm{H}, \mathrm{CH}), 4.28(\mathrm{td}$, $\left.J=5.7,1.4 \mathrm{~Hz}, 2 \mathrm{H}, \mathrm{CH}_{2}\right), 3.76\left(\mathrm{~s}, 3 \mathrm{H}, \mathrm{OCH}_{3}\right), 1.41(\mathrm{t}, J=5.9 \mathrm{~Hz}, 1 \mathrm{H}, \mathrm{OH}) .{ }^{13} \mathrm{C} \mathrm{NMR}(101$ $\left.\mathrm{MHz}, \mathrm{CDCl}_{3}\right) \delta 166.15(\mathrm{~d}, J=254.8 \mathrm{~Hz}), 163.81,151.30,139.43,135.92,132.99,132.89,129.73$ $(\mathrm{d}, J=156.2 \mathrm{~Hz}), 125.63(\mathrm{~d}, J=3.0 \mathrm{~Hz}), 122.94,119.22,115.74(\mathrm{~d}, J=22.0 \mathrm{~Hz}), 110.25,63.62$, 55.91. HRMS (ESI) calculated for $\mathrm{C}_{17} \mathrm{H}_{15} \mathrm{FO}_{4}[\mathrm{M}+\mathrm{H}]^{+}$303.09544, found 303.10255 .

4-(Hydroxymethyl)-2,6-dimethoxyphenyl 4-Fluorobenzoate (ABMM-23)

White solid; $68 \%$ yield; mp $105-107{ }^{\circ} \mathrm{C} .{ }^{1} \mathrm{H}$ NMR (400 MHz, DMSO) $\delta 8.84-8.21$ $(\mathrm{m}, 4 \mathrm{H}, \mathrm{ArH}), 7.85(\mathrm{~d}, J=7.7 \mathrm{~Hz}, 2 \mathrm{H}, \mathrm{ArH}), 4.06\left(\mathrm{~d}, J=6.9 \mathrm{~Hz}, 2 \mathrm{H}, \mathrm{CH}_{2}\right), 2.10-1.63(\mathrm{~m}, \mathrm{br}$, $1 \mathrm{H}, \mathrm{OH}),{ }^{13} \mathrm{C}$ NMR $\left(101 \mathrm{MHz}, \mathrm{CDCl}_{3}\right) \delta 168.20(\mathrm{~d}, J=256.1 \mathrm{~Hz}), 165.95,152.13(2 \mathrm{C}), 140.09$, $133.90(2 \mathrm{C}), 133.14(\mathrm{~d}, J=9.4 \mathrm{~Hz}), 125.14(\mathrm{~d}, J=3.0 \mathrm{~Hz}), 115.81(\mathrm{~d}, J=22.3 \mathrm{~Hz}, 2 \mathrm{C}), 106.14$ (2C), 65.6, 55.72 (2C). HRMS (ESI) calculated for $\mathrm{C}_{16} \mathrm{H}_{15} \mathrm{FO}_{4}\left[\mathrm{M}+\mathrm{NH}_{4}\right]^{+} 324.1242$, found 324.1183 .

(E)-3-(4-((4-Bromobenzyl)oxy)-3-methoxyphenyl)acrylaldehyde (ABMM-24)

Off-white solid; $44 \%$ yield; mp 98-100 ${ }^{\circ} \mathrm{C} .{ }^{1} \mathrm{H}$ NMR (400 MHz, DMSO) $\delta 9.62$ $(\mathrm{d}, J=7.8 \mathrm{~Hz}, 1 \mathrm{H}, \mathrm{CHO}), 7.65(\mathrm{~d}, \mathrm{~J}=15.8 \mathrm{~Hz}, 1 \mathrm{H}, \mathrm{CH}), 7.61(\mathrm{~d}, \mathrm{~J}=8.4 \mathrm{~Hz}, 2 \mathrm{H}, \mathrm{ArH})$, 7.43-7.39 (m, 3H, ArH), 7.28 (dd, J = 8.3, 1.8 Hz, 1H, ArH), 7.11 (d, J = 8.4 Hz, 1H, ArH), 6.83 $(\mathrm{dd}, J=15.8,7.8 \mathrm{~Hz}, 1 \mathrm{H}, \mathrm{CH}), 5.16\left(\mathrm{~s}, 2 \mathrm{H}, \mathrm{CH}_{2}\right), 3.84\left(\mathrm{~s}, 3 \mathrm{H}, \mathrm{OCH}_{3}\right) .{ }^{13} \mathrm{C} \mathrm{NMR}(101 \mathrm{MHz}$, DMSO) $\delta 194.65,153.95,150.80,149.80,136.61,131.87,130.40,127.85,127.26,123.95,121.58$, 
113.70, 111.42, 69.48, 56.22. HRMS (ESI) calculated for $\mathrm{C}_{17} \mathrm{H}_{15} \mathrm{BrO}_{3}[\mathrm{M}+\mathrm{H}]^{+}$347.0205, found 347.0211 .

(E)-3-(4-((4-Bromobenzyl)oxy)-3-methoxyphenyl)prop-2-en-1-ol (ABMM-25)

Pale yellow solid; $82 \%$ yield; mp 80-82 ${ }^{\circ} \mathrm{C} .{ }^{1} \mathrm{H}$ NMR (400 MHz, DMSO) $\delta 7.59$ $(\mathrm{d}, J=8.3 \mathrm{~Hz}, 2 \mathrm{H}, \mathrm{ArH}), 7.40(\mathrm{~d}, J=8.3 \mathrm{~Hz}, 2 \mathrm{H}, \mathrm{ArH}), 7.07(\mathrm{~s}, 1 \mathrm{H}, \mathrm{ArH}), 6.91(\mathrm{dt}, J=8.3$, $4.9 \mathrm{~Hz}, 2 \mathrm{H}, \mathrm{ArH}), 6.47(\mathrm{~d}, J=15.9 \mathrm{~Hz}, 1 \mathrm{H}, \mathrm{CH}), 6.27(\mathrm{dt}, J=15.9,5.2 \mathrm{~Hz}, 1 \mathrm{H}, \mathrm{CH}), 5.06$ $(\mathrm{s}, 2 \mathrm{H}, \mathrm{CH} 2), 4.82(\mathrm{t}, J=5.4 \mathrm{~Hz}, 1 \mathrm{H}, \mathrm{OH}), 4.10\left(\mathrm{t}, J=4.6 \mathrm{~Hz}, 2 \mathrm{H}, \mathrm{CH}_{2}\right), 3.80\left(\mathrm{~s}, 3 \mathrm{H}, \mathrm{OCH}_{3}\right)$. ${ }^{13} \mathrm{C}$ NMR (101 MHz, DMSO) $\delta 149.73,147.45,137.14,131.78,130.96,130.29,129.33,128.89$, $121.37,119.47,114.22,109.96,69.58,62.06,56.00$. HRMS (ESI) calculated for $\mathrm{C}_{17} \mathrm{H}_{17} \mathrm{BrO}_{3}[\mathrm{M}$ $+\mathrm{H}]^{+} 349.0361$, found 349.0451

(E)-3-(4-((4-Bromobenzyl)oxy)phenyl)acrylic Acid (ABMM-26)

Off-white solid; 61\% yield; mp 80-82 ${ }^{\circ} \mathrm{C} .{ }^{1} \mathrm{H}$ NMR (300 MHz, DMSO) $\delta 7.58$ $(\mathrm{d}, J=15.9 \mathrm{~Hz}, 1 \mathrm{H}, \mathrm{CH}), 7.44(\mathrm{~d}, J=8.3 \mathrm{~Hz}, 2 \mathrm{H}, \mathrm{ArH}), 7.37-7.13(\mathrm{~m}, 2 \mathrm{H}, \mathrm{ArH}), 7.13-6.90$ $(\mathrm{m}, 2 \mathrm{H}, \mathrm{ArH}), 6.85(\mathrm{~d}, J=8.2 \mathrm{~Hz}, 2 \mathrm{H}, \mathrm{ArH}), 6.25(\mathrm{~d}, J=15.9 \mathrm{~Hz}, 1 \mathrm{H}, \mathrm{CH}), 5.79\left(\mathrm{~s}, 2 \mathrm{H}, \mathrm{CH}_{2}\right)$ ${ }^{13}$ C NMR (75 MHz, DMSO) 8 166.91, 148.11, 146.76, 145.53, 135.23, 131.73, 129.91, 126.85, 123.22, 122.24, 114.93, 114.73, 109.33, 65.40, 55.94. HRMS (ESI) calculated for $\mathrm{C}_{16} \mathrm{H}_{13} \mathrm{BrO}_{3}$ $[\mathrm{M}+\mathrm{H}]^{+}$333.0048, found 333.0288.

(E)-3-(4-((4-Fluorobenzoyl)oxy)phenyl)acrylic Acid (ABMM-27)

Off-white solid; $41 \%$ yield; mp $112-114{ }^{\circ} \mathrm{C} .{ }^{1} \mathrm{H}$ NMR $(300 \mathrm{MHz}) \delta 8.16(\mathrm{dd}, \mathrm{J}=8.4$, $5.5 \mathrm{~Hz}, 2 \mathrm{H}, \mathrm{ArH}), 8.10-7.92(\mathrm{~m}, 2 \mathrm{H}, \mathrm{ArH}), 7.71(\mathrm{~d}, \mathrm{~J}=15.9 \mathrm{~Hz}, 1 \mathrm{H}, \mathrm{CH}), 7.29-6.95(\mathrm{~m}, 4 \mathrm{H}$, ArH), $6.37(\mathrm{~d}, \mathrm{~J}=15.9 \mathrm{~Hz}, 1 \mathrm{H}, \mathrm{CH}) .{ }^{13} \mathrm{C}$ NMR $(75 \mathrm{MHz}, \mathrm{DMSO}) \delta 171.71,170.53,166.25$ $(\mathrm{d}, \mathrm{J}=257.4 \mathrm{~Hz}), 151.65,146.25,141.91,132.98(\mathrm{~d}, \mathrm{~J}=13.0 \mathrm{~Hz}), 123.45,121.65,117.59,115.82$ $(\mathrm{d}, \mathrm{J}=22.0 \mathrm{~Hz})$, 111.54. HRMS (ESI) calculated for $\mathrm{C}_{16} \mathrm{H}_{11} \mathrm{FO}_{4}[\mathrm{M}+\mathrm{H}]^{+}$287.0641, found 287.0912 .

4-Formyl-2-methoxyphenyl 4-(Chloromethyl)benzoate (ABMM-28)

White solid; $48 \%$ yield; mp 93-95 ${ }^{\circ} \mathrm{C}$. NMR $(300 \mathrm{MHz}) \delta 9.93$ (s, 1H, CHO), 8.15 $(\mathrm{d}, J=8.1 \mathrm{~Hz}, 2 \mathrm{H}, \mathrm{ArH}), 7.79-7.12(\mathrm{~m}, 5 \mathrm{H}, \mathrm{ArH}), 4.60\left(\mathrm{~s}, 2 \mathrm{H}, \mathrm{CH}_{2}\right), 3.83\left(\mathrm{~s}, 3 \mathrm{H}, \mathrm{OCH}_{3}\right)$. NMR $(75 \mathrm{MHz}) \delta 191.07,163.64,152.16,145.11,143.26,135.35,131.00,130.84,128.97,128.80$, $128.74,124.78,123.54,110.92,56.14,45.26$. HRMS (ESI) calculated for $\mathrm{C}_{16} \mathrm{H}_{13} \mathrm{ClO}_{4}[\mathrm{M}+\mathrm{H}]^{+}$ 304.0502, found 304.0584.

4-Formylphenyl 4-(Chloromethyl)benzoate (ABMM-32)

White solid; $58 \%$ yield; mp 90-92 ${ }^{\circ} \mathrm{C}$. NMR $\left(300 \mathrm{MHz}, \mathrm{CDCl}_{3}\right) \delta 10.05$ (s, CHO), 8.22 $(\mathrm{d}, J=8.2 \mathrm{~Hz}, 2 \mathrm{H}, \mathrm{ArH}), 8.00(\mathrm{~d}, J=8.5 \mathrm{~Hz}, 2 \mathrm{H}, \mathrm{ArH}), 7.58(\mathrm{~d}, J=8.2 \mathrm{~Hz}, 2 \mathrm{H}, \mathrm{ArH}), 7.44$ $(\mathrm{d}, J=8.5 \mathrm{~Hz}, 2 \mathrm{H}, \mathrm{ArH}), 4.68\left(\mathrm{~s}, 2 \mathrm{H}, \mathrm{CH}_{2}\right)$. NMR $\left(75 \mathrm{MHz}, \mathrm{CDCl}_{3}\right) \delta 190.91,164.00,155.56$, $143.48,134.16,131.30,130.73,128.80,122.51,45.19$. HRMS (ESI) calculated for $\mathrm{C}_{15} \mathrm{H}_{11} \mathrm{ClO}_{3}$ $[\mathrm{M}+\mathrm{H}]^{+}$275.0397, found 275.0444.

(E)-2-Methoxy-4-(3-oxoprop-1-en-1-yl)phenyl 4-Nitrobenzoate (ABMM-33)

Yellow solid; $48 \%$ yield; mp 125-127 ${ }^{\circ} \mathrm{C}$. NMR (300 MHz, DMSO) $\delta 9.67(\mathrm{~d}, J=6.9 \mathrm{~Hz}$, CHO), 8.62-8.08 (m, 4H, ArH), $7.43(\mathrm{~d}, J=15.5 \mathrm{~Hz}, 1 \mathrm{H}, \mathrm{CH}), 7.25-6.92(\mathrm{~m}, 3 \mathrm{H}, \mathrm{ArH}), 6.65$ $(\mathrm{dd}, J=15.5,6.9 \mathrm{~Hz}, 1 \mathrm{H}, \mathrm{CH}), 3.82\left(\mathrm{~s}, 3 \mathrm{H}, \mathrm{OCH}_{3}\right)$. NMR (75 MHz, DMSO) $\delta 193.35,162.57$, $151.54,151.00,141.85,134.41,133.49,131.49,129.06,123.74,123.37,121.88,111.54,56.04$. HRMS (ESI) calculated for $\mathrm{C}_{17} \mathrm{H}_{14} \mathrm{NO}_{6}[\mathrm{M}+\mathrm{H}]^{+} 328.0743$, found 328.0822 .

2-Formylphenyl 4-Chlorobenzoate (ABMM-34)

White solid; $74 \%$ yield; $\mathrm{mp} 85-87^{\circ} \mathrm{C}$. NMR ( $\left.300 \mathrm{MHz}, \mathrm{CDCl}_{3}\right) \delta 10.11$ (s, $\left.1 \mathrm{H}, \mathrm{CHO}\right)$, $8.11(\mathrm{~d}, J=8.2 \mathrm{~Hz}, 2 \mathrm{H}, \mathrm{ArH}), 8.02(\mathrm{~d}, J=8.3 \mathrm{~Hz}, 1 \mathrm{H}, \mathrm{ArH}), 7.89(\mathrm{~d}, J=7.6 \mathrm{~Hz}, 1 \mathrm{H}, \mathrm{ArH})$, 7.68-7.58 (m, 1H, ArH), $7.46(\mathrm{~d}, J=8.2 \mathrm{~Hz}, 2 \mathrm{H}, \mathrm{ArH}), 7.26(\mathrm{~d}, J=8.0 \mathrm{~Hz}, 1 \mathrm{H}, \mathrm{ArH}) . \mathrm{NMR}$ $\left(75 \mathrm{MHz}, \mathrm{CDCl}_{3}\right) \delta 188.44,135.39,131.88,131.72,131.66,130.94,129.38,129.17,128.91$, 
126.67, 126.33, 124.04, 123.52. HRMS (ESI) calculated for $\mathrm{C}_{14} \mathrm{H}_{9} \mathrm{ClO}_{3}[\mathrm{M}+\mathrm{H}]^{+}$261.0240, found 261.0316 .

4-(Hydroxymethyl)phenyl 4-Chlorobenzoate (ABMM-35)

White solid; 64\% yield; mp 93-95 ${ }^{\circ} \mathrm{C}$. NMR $\left(300 \mathrm{MHz}, \mathrm{CDCl}_{3}\right) \delta 8.08(\mathrm{~d}, J=7.3 \mathrm{~Hz}$, $2 \mathrm{H}, \mathrm{ArH}), 7.41(\mathrm{~m}, 4 \mathrm{H}, \mathrm{ArH}), 7.14(\mathrm{~d}, J=7.3 \mathrm{~Hz}, 2 \mathrm{H}, \mathrm{ArH}), 4.67\left(\mathrm{~s}, 2 \mathrm{H}, \mathrm{CH}_{2}\right), 1.64(\mathrm{~s}, 1 \mathrm{H}$, $\mathrm{OH})$. NMR (75 MHz, $\left.\mathrm{CDCl}_{3}\right) \delta 164.40,150.18,140.20,138.72,131.56,128.97,128.19,127.94$, 121.74, 64.79. HRMS (ESI) calculated for $\mathrm{C}_{14} \mathrm{H}_{11} \mathrm{ClO}_{3}[\mathrm{M}+\mathrm{H}]^{+}$263.0397, found 263.0475.

\subsection{Purification of Recombinant Human ALDHs and Enzymatic Assays}

Human ALDH1A1 and ALDH1A3 were cloned, recombinantly expressed and affinitypurified as previously described [30]. Human ALDH3A1 was also cloned and recombinantly expressed from the pET-30 Xa/LIC vector and purified using the same procedure. Enzymes including the $\mathrm{N}$-terminal (His) 6 tag were stored at $-20^{\circ} \mathrm{C}$ in $20 \mathrm{mM}$ Tris $/ \mathrm{HCl}$, $0.5 \mathrm{M} \mathrm{NaCl}, \mathrm{pH}$ 8.0, and $5 \mathrm{mM}$ DTT until use. Activity under standard conditions was measured fluorimetrically to follow the purification procedure and to check the enzyme concentration before each kinetic experiment. Standard activity of each isoform was measured using specific reaction buffers and at saturating concentrations of substrate, as described below.

\subsection{Inhibition Screening}

Single-point measurements of enzymatic activity at $10 \mu \mathrm{M}$ inhibitor were performed at $25^{\circ} \mathrm{C}$ using a Cary Eclipse (Varian) fluorimeter. The dehydrogenase activity was monitored by following the $\mathrm{NAD}(\mathrm{P}) \mathrm{H}$ fluorescence, by sample excitation at $340 \mathrm{~nm}$ and fluorescence emission at $460 \mathrm{~nm}$. The enzymatic reaction was initiated by the addition of the substrate to a $1 \mathrm{~mL}$ quartz cuvette containing the enzyme and the cofactor. The reaction mixture also contained $5 \mu \mathrm{M}$ of $\mathrm{NAD}(\mathrm{P}) \mathrm{H}$ as an internal standard to obtain absolute reaction rates, as described [30,49]. Assays without enzyme were always carried out as a control to ensure the absence of activity. The reaction buffer was $50 \mathrm{mM}$ HEPES, $0.5 \mathrm{mM}$ EDTA and $0.5 \mathrm{mM}$ DTT, $\mathrm{pH}$ 8.0, for ALDH1A1; $50 \mathrm{mM}$ HEPES, $50 \mathrm{mM} \mathrm{MgCl}{ }_{2}$ and $5 \mathrm{mM}$ DTT, $\mathrm{pH}$ 8.0, for ALDH1A3; and $50 \mathrm{mM}$ Tris- $\mathrm{HCl}$ and $5 \mathrm{mM}$ DTT, $\mathrm{pH}$ 8.0, for ALDH3A1. Hexanal was used as the standard substrate for ALDH1A1 and ALDH1A3, while 4-nitrobenzaldehyde (4-NBA) was used as the substrate for ALDH3A1. The assay was typically performed at saturating substrate concentrations $(30 \mu \mathrm{M}$ hexanal for ALDH1A1, $250 \mu \mathrm{M}$ hexanal for ALDH1A3 and $250 \mu \mathrm{M} 4$-NBA for ALDH3A1). ALDH1A3 activity was also measured at a substrate concentration near the $K_{m}$ value $(10 \mu \mathrm{M}$ hexanal). All substrates were prepared at a concentration of $2 \mathrm{mM}$ and further diluted to reach the final concentrations required per experiment. All tested compounds were dissolved in DMSO and assayed at a final concentration of $1 \%(v / v)$ DMSO. In all assays, the reaction took place in a final volume of $1 \mathrm{~mL}$ and in the presence of $0.5 \mathrm{mM} \mathrm{NAD}^{+}$for ALDH1A1/ALDH1A3 or $1 \mathrm{mM} \mathrm{NADP}^{+}$ for ALDH3A1, and $10 \mu \mathrm{M}$ inhibitor or $1 \%$ DMSO for the control. The concentration of enzyme was kept from 50- to 100-fold lower than that of the substrate for all enzymatic assays. The reaction mixture was pre-incubated for $5 \mathrm{~min}$ at room temperature (except for the slow-binding assay where the mixture was pre-incubated for $20 \mathrm{~min}$ ) before the substrate was added to initiate the reaction. All assays were performed as duplicates and the results are expressed as the mean, with a relative error always lower than $30 \%$. The results are presented as the percentage of remaining activity, which is calculated as the ratio of activity in presence of inhibitor versus that of the control with $1 \%$ DMSO.

\subsection{Determination of Half-Maximal Inhibitory Concentrations $\left(I_{50}\right)$}

$\mathrm{IC}_{50}$ values of enzymatic activity were determined for the two best inhibitor candidates against ALDH1A3. Reaction rates were determined at various inhibitor concentrations at a fixed substrate concentration. The $\mathrm{IC}_{50}$ values were calculated by a non-linear fitting of the experimental data to a sigmoidal plot using GraFit 5.0 (Erithacus software), with the 
following 4-parameter equation: $y=\frac{\text { range }}{1+\left(\frac{x}{I_{50}}\right)^{s}}+$ background, where $y$ is the specific activity, $\mathrm{x}$ is the inhibitor concentration, background is the minimum $\mathrm{y}$ value, range is the fitted uninhibited value minus the background, and s is a slope factor. Reaction conditions were the same as those described in Section 3.3, and $250 \mu \mathrm{M}$ hexanal was used as the substrate.

\subsection{Biology}

\subsubsection{Cell Culture}

A549 and H1299 human NSCLC cell lines were cultured in RPMI-1640 medium, supplemented with $10 \%(v / v)$ heat inactivated fetal bovine serum and $(2 \mathrm{mmol} / \mathrm{L}) \mathrm{L}$-glutamine. The cells were maintained in $5 \% \mathrm{CO}_{2}$ humidified incubator at $37^{\circ} \mathrm{C}$.

\subsubsection{Cytotoxicity Experiment}

A549 and H1299 cells were seeded at 750 and 1000 cells per well, respectively, into 96-well plates and left overnight to allow cell attachment. Cells were then treated with different compounds at various concentrations ranging between 0.01 and $60 \mu \mathrm{M}$ for $24 \mathrm{~h}$ or $96 \mathrm{~h}$. For the shorter exposure period, the drug-containing medium was removed after $24 \mathrm{~h}$ and replenished with fresh growth medium for the remainder of the $96 \mathrm{~h}$ period. The number of surviving cells was then determined using MTT (3-(4,5-dimethylthiazole-2-yl)2,5-diphenyltetrazolium bromide) Cell Viability Assays, according to the Assay Guidance Manual [50]. MTT solution $(2.5 \mathrm{mg} / \mathrm{mL})$ was prepared in sterile PBS. Following $93 \mathrm{~h}$ of incubation, $50 \mu \mathrm{L}$ MTT solution was added to the cells and incubated for $3 \mathrm{~h}$ at $37^{\circ} \mathrm{C}$. The medium was then removed and the remaining formazan crystals were dissolved in $200 \mu \mathrm{L}$ DMSO (TEDIA, USA). Optical densities were then measured on a SynergyHTX ${ }^{\circledR}$ spectrophotometer at $540 \mathrm{~nm}$ and then analyzed using Gen5 Software package. The results were then used to calculate the surviving fraction of cells relative to solvent-only controls. Dose-response curves were generated using the GraphPad Prism 7 Software, and nonlinear regression analysis was used to fit the data. $\mathrm{IC}_{50}$ values (defined as the concentration of drug required to decrease cell survival by $50 \%$ relative to controls) were determined from these curves.

\subsection{In Silico Study \\ 3.6.1. Protein and Ligand Preparation}

The X-ray structure of human ALDH1A1 in complex with 1-\{[1,3-dimethyl-7-(3methylbutyl)-2,6-dioxo-2,3,6,7-tetrahydro-1H-purin-8-yl]methyl\}piperidine-4-carboxamide (PDB ID: 4WPN), human ALDH1A3 in complex with RA and NAD+ (PDB ID: 5FHZ) and human ALDH3A1 in complex with selective inhibitor N-[4-(4-methylsulfonyl-2nitroanilino)phenyl]acetamide (PDB ID: 4H80) were downloaded from the Protein Data Bank $[29,51,52]$. The resolution of the X-ray structures was found to be $1.95,2.90$, and $2.50 \AA$ for ALDH1A1, ALDH1A3 and ALDH3A1, respectively. All the structures were primarily selected, after satisfying the X-ray diffraction resolution of not more than $3.0 \AA$ (higher values are associated with poor quality). Furthermore, the X-ray structures for ALDH1A1 and ALDH3A1 were selected based on the presence of a selective co-crystallized inhibitor, which should have a reasonable inhibitory effect $\left(\mathrm{IC}_{50}, \mathrm{~K}_{\mathrm{i}}\right)$ and should demonstrate a significant no. of H-bond and hydrophobic contacts within the binding site, which could be exploited to compare with the synthesized analogues. The X-ray structure of human ALDH1A3 is co-crystallized with the reaction product retinoic acid (RA), which forms H-bond interactions with the active site C313/C314/T315 residues, whereas other available X-crystal structures of ALDH1A3, which have co-crystallized inhibitors, do not exemplify the $\mathrm{H}$-bond interactions with these catalytic residues, and thus the $\mathrm{X}$-ray structure of ALDH1A3 with PDB ID, 5FHZ, was chosen in our study. The co-crystallized ligands, ions and water molecules were removed from the $\mathrm{X}$-ray complexes and $\mathrm{H}$-bonds, and missing residues were added to the protein with the aid of the protein preparation wizard of Maestro. All the compounds were drawn using the Build panel of Maestro and subjected to LigPrep tool interfaced with the Maestro module of Schrödinger suite. The 3D structures, 
including all possible tautomers and ionization states at $\mathrm{pH} 7.0 \pm 2.0$ of all the compounds, were generated and geometrically minimized using OPLS3e force field.

\subsubsection{Molecular Docking}

All docking calculations were carried out on the above-mentioned X-ray structures of ALDH1A1, ALDHA3 and ALDH3A1. Glide 5.0 with standard precision (SP) method [53] was used for the docking of all compounds.

GLIDE 5.0. The binding site was defined by a rectangular box of $10 \AA$ in the $x, y$, and $z$ directions centered on the ligand. The GLIDE defaults were used for all parameter settings. The GlideScore fitness function is based on Chemscore but includes a steric-clash term, adds buried polar terms to penalize electrostatic mismatches and involves modifications on other secondary terms. The docking analyses were carried out using the Standard Precision (SP) method. A total of 50 docking solutions were generated for each ligand, and the top-ranked docking pose was considered the final pose.

The reliability of the docking program: Glide 5.0 was assessed by performing selfdocking analysis and calculating the root-mean-square deviation (RMSD) between the crystallographic position of the ligand and the ligand's disposition predicted by docking. The rms_analysis program of Gold suite was used to calculate the RMSD difference, considering only the heavy atoms of the ligand. The docking method is able to produce a binding pose within $2.0 \AA$ RMSD of the crystallographic disposition; therefore, it is considered reliable [54].

\subsubsection{Visualization of the Docked Poses}

Two-dimensional and three-dimensional images of all the docked poses were generated by using Discovery Studio Client 2021.

\section{Conclusions}

In summary, we implemented several experiments to prove that ABMM-15 and ABMM-16, which are based on a benzyloxybenzaldehyde scaffold, act as selective ALDH1A3 inhibitors. For this purpose, these two compounds were evaluated against two other isoforms (ALDH1A1 and ALDH3A1) and showed no significant inhibition of their activities. Other isoforms, such as ALDH1A2 and ALDH2, might be of interest to be kinetically assayed using $A B M M-15$ and $A B M M-16$ to better assert their selective inhibition of ALDH1A3. The IC 50 values for these two compounds on ALDH1A3 were promising, which could potentially be considered for therapeutic intervention via further compound optimization. Accordingly, both ABMM-15 and ABMM-16 were evaluated alone in a panel of two NSCLC cell lines (including ALDH-positive A549 and ALDH-negative H1299 cells), and toxicity was clearly absent at the maximum concentration of $60 \mu \mathrm{M}$. However, these results suggest that ABMM- 15 and ABMM-16 can be used in a wide range of nontoxic concentrations, in which they may have a potential role in diminishing the chemoresistance of certain anticancer drugs when used in combination therapy. Hence, further research on investigating their cytotoxicity alone and in combination with anticancer drugs in drugresistant cancer cell lines, particularly those expressing elevated levels of the ALDH1A3 isoform, is worth pursuing. In addition, more analogues for ABMM-15 can also be designed, synthesized and evaluated for ALDH isoform selectivity and in a panel of cancer cell lines to obtain a broader conclusive SAR study.

The synthesized coniferyl aldehyde analogues were also found to be interesting regarding their enhanced cytotoxicity on H1299 cell lines, but with insignificant ALDH inhibition. Therefore, the mechanistic pathway of their selective toxicity remains unknown and warrants further investigation.

Supplementary Materials: ${ }^{1} \mathrm{H}-\mathrm{NMR},{ }^{13} \mathrm{C}-\mathrm{NMR}$ and HRMS for the synthesized compounds can be found in the Supplementary Materials. 
Author Contributions: A.I.M.I. and K.P. designed the study. A.I.M.I., W.K.A. and K.T.J. performed the chemical experiments, B.I. performed the cytotoxicity experiments, E.B., R.J. and R.P. performed enzyme purification and kinetic assay experiments, and V.J. performed the computational studies. The first draft of the manuscript was written by A.I.M.I., edited and reviewed by A.I.M.I., E.B., V.J., J.F., X.P. and K.P. All authors have given approval to the final version of the manuscript. All authors have contributed to editorial improvements of the first draft. All authors have read and agreed to the published version of the manuscript.

Funding: "This research was funded by Al-Zaytoonah University of Jordan, grant number 20192018/18/03", by the Spanish Ministerio de Ciencia e Innovación, grant number PID2020-119424RBI00 and by "UoB International Development Fund Scheme PhD, grant code studentship to E.B.". R.J. is a recipient of a PIF predoctoral fellowship from Universitat Autònoma de Barcelona.

Institutional Review Board Statement: Not applicable.

Informed Consent Statement: Not applicable.

Data Availability Statement: Data is contained within the article and in the Supplementary Materials.

Acknowledgments: All authors thank Goreti Ribeiro Morais and Hassan Abul-Futouh for their support in the characterization of the synthesized compounds.

Conflicts of Interest: The authors declare no conflict of interest. The funders had no role in the design of the study; in the collection, analyses, or interpretation of data; in the writing of the manuscript, or in the decision to publish the results.

Sample Availability: Not applicable.

\section{Abbreviations}

ALDH, aldehyde dehydrogenase; $\mathrm{NAD}^{+}$, nicotinamide adenine dinucleotide; $\mathrm{NADH}$, nicotinamide adenine dinucleotide reduced form; RA, retinoic acid; DEAB, diethylamino benzaldehyde; SCs, stem cells; CSCs, cancer stem cells; TLC, thin layer chromatography; HRMS, high resolution mass spectrometry; 4-NBA, 4-nitrobenzaldehyde; 1H-NMR, proton nuclear magnetic resonance; ${ }^{13} \mathrm{C}-\mathrm{NMR}$, carbon-13 nuclear magnetic resonance; DMSO, dimethylsulfoxide; Hz, hertz; MHz, megahertz; DMF, dimethylformamide; Rf, retention factor; $\mathrm{mp}$, melting point; $\mathrm{RMSD}$, root-mean-square deviation; $\mathrm{IC}_{50}$, half-maximal inhibitory concentration; PDB, protein data bank; NSCLC, non-small cell lung cancer; MTT, (3-(4,5-dimethylthiazole-2-yl)-2,5-diphenyltetrazolium bromide); PBS, phosphatebuffered saline.

\section{References}

1. Kelson, T.L.; McVoy, J.R.S.; Rizzo, W.B. Human liver fatty aldehyde dehydrogenase: Microsomal localization, purification, and biochemical characterization. Biochim. Biophys. Acta BBA Gen. Subj. 1997, 1335, 99-110. [CrossRef]

2. Arnold, S.L.; Kent, T.; Hogarth, C.; Griswold, M.D.; Amory, J.; Isoherranen, N. Pharmacological inhibition of ALDH1A in mice decreases all-trans retinoic acid concentrations in a tissue specific manner. Biochem. Pharmacol. 2015, 95, 177-192. [CrossRef]

3. Ang, H.L.; Duester, G. Retinoic acid biosynthetic enzyme ALDH1 localizes in a subset of retinoid-dependent tissues during xenopus development. Dev. Dyn. 1999, 215, 264-272. [CrossRef]

4. Albalat, R.; Cañestro, C. Identification of Aldh1a, Cyp26 and RAR orthologs in protostomes pushes back the retinoic acid genetic machinery in evolutionary time to the bilaterian ancestor. Chem. Interact. 2009, 178, 188-196. [CrossRef]

5. Neuville, P.; Yan, Z.-q.; Gidlöf, A.; Pepper, M.S.; Hansson, G.K.; Gabbiani, G.; Sirsjö, A. Retinoic acid regulates arterial smooth muscle cell proliferation and phenotypic features in vivo and in vitro through an RAR $\alpha$-dependent signaling pathway. Arterioscler. Thromb. Vasc. Biol. 1999, 19, 1430-1436. [CrossRef] [PubMed]

6. Goodman, T.; Crandall, J.E.; Nanescu, S.E.; Quadro, L.; Shearer, K.; Ross, A.; McCaffery, P. Patterning of retinoic acid signaling and cell proliferation in the hippocampus. Hippocampus 2012, 22, 2171-2183. [CrossRef]

7. Crowe, D.L.; Kim, R.; Chandraratna, R.A.S. Retinoic acid differentially regulates cancer cell proliferation via dose-dependent modulation of the mitogen-activated protein kinase pathway. Mol. Cancer Res. 2003, 1, 532-540. [PubMed]

8. Karsy, M.; Albert, L.; Tobias, M.E.; Murali, R.; Jhanwar-Uniyal, M. All-trans retinoic acid modulates cancer stem cells of glioblastoma multiforme in an MAPK-dependent manner. Anticancer Res. 2010, 30, 4915-4920. [PubMed]

9. Marcato, P.; Dean, C.A.; Giacomantonio, C.A.; Lee, P.W. Aldehyde dehydrogenase: Its role as a cancer stem cell marker comes down to the specific isoform. Cell Cycle 2011, 10, 1378-1384. [CrossRef] [PubMed] 
10. Rodriguez-Torres, M.; Allan, A.L. Aldehyde dehydrogenase as a marker and functional mediator of metastasis in solid tumors. Clin. Exp. Metastasis 2016, 33, 97-113. [CrossRef]

11. Toledo-Guzmán, M.E.; Hernández, M.I.; Gómez-Gallegos, Á.A.; Ortiz-Sánchez, E. ALDH as a stem cell marker in solid tumors. Curr. Stem Cell Res. Ther. 2019, 14, 375-388. [CrossRef]

12. Carpentino, J.E.; Hynes, M.J.; Appelman, H.D.; Zheng, T.; Steindler, D.A.; Scott, E.W.; Huang, E.H. Aldehyde dehydrogenaseexpressing colon stem cells contribute to tumorigenesis in the transition from colitis to cancer. Cancer Res. 2009, 69, 8208-8215. [CrossRef]

13. Charafe-Jauffret, E.; Ginestier, C.; Iovino, F.; Tarpin, C.; Diebel, M.; Esterni, B.; Houvenaeghel, G.; Extra, J.-M.; Bertucci, F.; Jacquemier, J.; et al. Aldehyde dehydrogenase 1-positive cancer stem cells mediate metastasis and poor clinical outcome in inflammatory breast cancer. Clin. Cancer Res. 2009, 16, 45-55. [CrossRef] [PubMed]

14. Mao, P.; Joshi, K.; Li, J.; Kim, S.-H.; Li, P.; Santana-Santos, L.; Luthra, S.; Chandran, U.R.; Benos, P.; Smith, L.; et al. Mesenchymal glioma stem cells are maintained by activated glycolytic metabolism involving aldehyde dehydrogenase 1A3. Proc. Natl. Acad. Sci. USA 2013, 110, 8644-8649. [CrossRef] [PubMed]

15. Pors, K.; Moreb, J.S. Aldehyde dehydrogenases in cancer: An opportunity for biomarker and drug development? Drug Discov. Today 2014, 19, 1953-1963. [CrossRef]

16. Marcato, P.; Dean, C.A.; Pan, D.; Araslanova, R.; Gillis, M.; Joshi, M.; Helyer, L.; Pan, L.; Leidal, A.; Gujar, S.; et al. Aldehyde dehydrogenase activity of breast cancer stem cells is primarily due to isoform ALDH1A3 and Its expression is predictive of metastasis. Stem Cells 2011, 29, 32-45. [CrossRef] [PubMed]

17. Codony-Servat, J.; Servat, C.C.; Cardona, A.F.; Giménez-Capitán, A.; Drozdowskyj, A.; Berenguer, J.; Bracht, J.W.P.; Ito, M.; Karachaliou, N.; Rosell, R. Cancer stem cell biomarkers in EGFR-mutation-positive non-small-cell lung cancer. Clin. Lung Cancer 2019, 20, 167-177. [CrossRef] [PubMed]

18. Zhang, W.; Liu, Y.; Hu, H.; Huang, H.; Bao, Z.; Yang, P.; Wang, Y.; You, G.; Yan, W.; Jiang, T.; et al. ALDH1A3: A marker of mesenchymal phenotype in gliomas associated with cell invasion. PLoS ONE 2015, 10, e0142856. [CrossRef]

19. Thomas, M.L.; de Antueno, R.; Coyle, K.; Sultan, M.; Cruickshank, B.M.; Giacomantonio, M.A.; Giacomantonio, C.A.; Duncan, R.; Marcato, P. Citral reduces breast tumor growth by inhibiting the cancer stem cell marker ALDH1A3. Mol. Oncol. 2016, 10, 1485-1496. [CrossRef]

20. Canino, C.; Luo, Y.; Marcato, P.; Blandino, G.; Pass, H.; Cioce, M. A STAT3-NFkB/DDIT3/CEBP $\beta$ axis modulates ALDH1A3 expression in chemoresistant cell subpopulations. Oncotarget 2015, 6, 12637-12653. [CrossRef] [PubMed]

21. Kurth, I.; Hein, L.; Mäbert, K.; Peitzsch, C.; Koi, L.; Cojoc, M.; Kunz-Schughart, L.; Baumann, M.; Dubrovska, A. Cancer stem cell related markers of radioresistance in head and neck squamous cell carcinoma. Oncotarget 2015, 6, 34494-34509. [CrossRef] [PubMed]

22. Gelardi, E.; Colombo, G.; Picarazzi, F.; Ferraris, D.; Mangione, A.; Petrarolo, G.; Aronica, E.; Rizzi, M.; Mori, M.; La Motta, C.; et al. A selective competitive inhibitor of aldehyde dehydrogenase $1 \mathrm{~A} 3$ hinders cancer cell growth, invasiveness and stemness in vitro. Cancers 2021, 13, 356. [CrossRef]

23. Pan, M.; Li, M.; You, C.; Zhao, F.; Guo, M.; Xu, H.; Li, L.; Wang, L.; Dou, J. Inhibition of breast cancer growth via miR-7 suppressing ALDH1A3 activity concomitant with decreasing breast cancer stem cell subpopulation. J. Cell. Physiol. 2020, 235, 1405-1416. [CrossRef]

24. Khanna, M.; Chen, C.-H.; Kimble-Hill, A.; Parajuli, B.; Perez-Miller, S.; Baskaran, S.; Kim, J.; Dria, K.; Vasiliou, V.; Mochly-Rosen, D.; et al. Discovery of a novel class of covalent inhibitor for aldehyde dehydrogenases. J. Biol. Chem. 2011, 286, 43486-43494. [CrossRef] [PubMed]

25. Laskar, A.A.; Alam Khan, M.; Ahmad, S.; Hashmi, A.; Younus, H. Citral inhibition of human salivary aldehyde dehydrogenase. Cell Biophys. 2019, 78, 31-42. [CrossRef] [PubMed]

26. Luo, M.; Gates, K.S.; Henzl, M.T.; Tanner, J.J. Diethylaminobenzaldehyde is a covalent, irreversible inactivator of ALDH7A1. ACS Chem. Biol. 2015, 10, 693-697. [CrossRef] [PubMed]

27. Farrés, J.; Wang, T.T.Y.; Cunningham, S.J.; Weiner, H. Investigation of the active site cysteine residue of rat liver mitochondrial aldehyde dehydrogenase by site-directed mutagenesis. Biochemistry 1995, 34, 2592-2598. [CrossRef]

28. Kopečný, D.; Tylichová, M.; Snégaroff, J.; Popelková, H.; Šebela, M. Carboxylate and aromatic active-site residues are determinants of high-affinity binding of $\omega$-aminoaldehydes to plant aminoaldehyde dehydrogenases. FEBS J. 2011, 278, 3130-3139. [CrossRef]

29. Moretti, A.; Li, J.; Donini, S.; Sobol, R.W.; Rizzi, M.; Garavaglia, S. Crystal structure of human aldehyde dehydrogenase 1A3 complexed with NAD+ and retinoic acid. Sci. Rep. 2016, 6, 35710. [CrossRef]

30. Pequerul, R.; Vera, J.; Giménez-Dejoz, J.; Crespo, I.; Coines, J.; Porté, S.; Rovira, C.; Parés, X.; Farrés, J. Structural and kinetic features of aldehyde dehydrogenase 1A (ALDH1A) subfamily members, cancer stem cell markers active in retinoic acid biosynthesis. Arch. Biochem. Biophys. 2020, 681, 108256. [CrossRef]

31. Riveros-Rosas, H.; González-Segura, L.; Julián-Sánchez, A.; Díaz-Sanchez, Á.; Muñoz-Clares, R.A. Structural determinants of substrate specificity in aldehyde dehydrogenases. Chem. Interact. 2013, 202, 51-61. [CrossRef] [PubMed]

32. Cao, S.; Bian, Y.; Zhou, X.; Yuan, Q.; Wei, S.; Xue, L.; Yang, F.; Dong, Q.; Wang, W.; Zheng, B.; et al. A small-molecule activator of mitochondrial aldehyde dehydrogenase 2 reduces the severity of cerulein-induced acute pancreatitis. Biochem. Biophys. Res. Commun. 2019, 522, 518-524. [CrossRef] [PubMed] 
33. Chen, Y.; Zhu, J.-Y.; Hong, K.H.; Mikles, D.C.; Georg, G.I.; Goldstein, A.S.; Amory, J.; Schonbrunn, E. Structural basis of ALDH1A2 inhibition by irreversible and reversible small molecule inhibitors. ACS Chem. Biol. 2017, 13, 582-590. [CrossRef]

34. Parajuli, B.; Georgiadis, T.M.; Fishel, M.L.; Hurley, T.D. Development of selective inhibitors for human aldehyde dehydrogenase 3A1 (ALDH3A1) for the enhancement of cyclophosphamide cytotoxicity. ChemBioChem 2014, 15, 701-712. [CrossRef]

35. Morgan, C.A.; Parajuli, B.; Buchman, C.D.; Dria, K.; Hurley, T.D. N,N-diethylaminobenzaldehyde (DEAB) as a substrate and mechanism-based inhibitor for human ALDH isoenzymes. Chem. Interact. 2015, 234, 18-28. [CrossRef] [PubMed]

36. Weiner, H.; Hu, J.H.; Sanny, C.G. Rate-limiting steps for the esterase and dehydrogenase reaction catalyzed by horse liver aldehyde dehydrogenase. J. Biol. Chem. 1976, 251, 3853-3855. [CrossRef]

37. Rodríguez-Zavala, J.S.; Allali-Hassani, A.; Weiner, H. Characterization of E. coli tetrameric aldehyde dehydrogenases with atypical properties compared to other aldehyde dehydrogenases. Protein Sci. 2006, 15, 1387-1396. [CrossRef]

38. Parajuli, B.; Kimble-Hill, A.C.; Khanna, M.; Ivanova, Y.; Meroueh, S.; Hurley, T.D. Discovery of novel regulators of aldehyde dehydrogenase isoenzymes. Chem. Interact. 2011, 191, 153-158. [CrossRef]

39. Park, J.W.; Jung, K.-H.; Lee, J.H.; Moon, S.H.; Cho, Y.S.; Lee, K.-H. Inhibition of aldehyde dehydrogenase 1 enhances the cytotoxic effect of retinaldehyde on A549 cancer cells. Oncotarget 2017, 8, 99382-99393. [CrossRef] [PubMed]

40. Moreb, J.S.; Zucali, J.R.; Ostmark, B.; Benson, N.A. Heterogeneity of aldehyde dehydrogenase expression in lung cancer cell lines is revealed by Aldefluor flow cytometry-based assay. Cytom. Part B Clin. Cytom. 2007, 72B, 281-289. [CrossRef]

41. Zhang, J.-H.; Liu, L.-Q.; He, Y.-L.; Kong, W.-J.; Huang, S.-A. Cytotoxic effect of trans-cinnamaldehyde on human leukemia K562 cells. Acta Pharmacol. Sin. 2010, 31, 861-866. [CrossRef] [PubMed]

42. Najar, B.; Shortrede, J.; Pistelli, L.; Buhagiar, J. Chemical composition and in vitro cytotoxic screening of sixteen commercial essential oils on five cancer cell lines. Chem. Biodivers. 2019, 17, e1900478. [CrossRef] [PubMed]

43. Yu, C.; Liu, S.-L.; Qi, M.-H.; Zou, X. Cinnamaldehyde/chemotherapeutic agents interaction and drug-metabolizing genes in colorectal cancer. Mol. Med. Rep. 2013, 9, 669-676. [CrossRef] [PubMed]

44. Park, J.; Baek, S.H. Combination therapy with cinnamaldehyde and hyperthermia induces apoptosis of A549 non-small cell lung carcinoma cells via regulation of reactive oxygen species and mitogen-activated protein kinase family. Int. J. Mol. Sci. 2020, 21, 6229. [CrossRef]

45. Hosseinzadeh, L.; Abbasi, A.; Hajialyani, M.; Jalilian, F.; Yaghmaei, P.; Navid, S.J.; Motamed, H. Evaluation of the cytotoxic and apoptogenic effects of cinnamaldehyde on U87MG cells alone and in combination with doxorubicin. Res. Pharm. Sci. 2020, 15, 26-35. [CrossRef] [PubMed]

46. Cabello, C.M.; Bair, W.B.; Lamore, S.D.; Ley, S.; Bause, A.S.; Azimian, S.; Wondrak, G.T. The cinnamon-derived Michael acceptor cinnamic aldehyde impairs melanoma cell proliferation, invasiveness, and tumor growth. Free. Radic. Biol. Med. 2009, 46, $220-231$. [CrossRef]

47. Sudanich, S.; Tiyaworanant, S.; Yenjai, C. Cytotoxicity of flavonoids and isoflavonoids from Crotalaria bracteata. Nat. Prod. Res. 2017, 31, 2641-2646. [CrossRef]

48. Croker, A.K.; Allan, A.L. Inhibition of aldehyde dehydrogenase (ALDH) activity reduces chemotherapy and radiation resistance of stem-like ALDHhiCD44+ human breast cancer cells. Breast Cancer Res. Treat. 2011, 133, 75-87. [CrossRef] [PubMed]

49. Sołobodowska, S.; Giebultowicz, J.; Wolinowska, R.; Wroczyński, P. Contribution of ALDH1A1 isozyme to detoxification of aldehydes present in food products. Acta Pol. Pharm. Drug Res. 2013, 69, 1380-1383.

50. Markossian, S.; Grossman, A.; Brimacombe, K.; Arkin, M.; Auld, D.; Austin, C.P.; Baell, J.; Chung, T.D.Y.; Coussens, N.P.; Dahlin, J.L.; et al. Assay Guidance Manual; Eli Lilly \& Company: Indianapolis, IN, USA; National Center for Advancing Translational Sciences: Bethesda, MD, USA, 2004.

51. Berman, H.M.; Westbrook, J.; Feng, Z.; Gilliand, G.; Bhat, T.N.; Weissig, H.; Shindyalov, I.N.; Bourne, P.E. The protein data bank. Nucleic Acids Res. 2000, 28, 235-242. [CrossRef]

52. Morgan, C.A.; Hurley, T. Characterization of two distinct structural classes of selective aldehyde dehydrogenase $1 \mathrm{~A} 1$ inhibitors. J. Med. Chem. 2015, 58, 1964-1975. [CrossRef] [PubMed]

53. Halgren, T.A.; Murphy, R.B.; Friesner, R.A.; Beard, H.S.; Frye, L.L.; Pollard, W.T.; Banks, J.L. Glide: A new approach for rapid, accurate docking and scoring. 2. enrichment factors in database screening. J. Med. Chem. 2004, 47, 1750-1759. [CrossRef] [PubMed]

54. Liebeschuetz, J.W.; Cole, J.C.; Korb, O. Pose prediction and virtual screening performance of GOLD scoring functions in a standardized test. J. Comput. Mol. Des. 2012, 26, 737-748. [CrossRef] [PubMed] 